\title{
Origin and processing of terrestrial organic carbon in the Amazon system: lignin phenols in river, shelf, and fan sediments
}

\author{
Shuwen Sun ${ }^{1,2,7}$, Enno Schefuß ${ }^{2}$, Stefan Mulitza $^{2}$, Cristiano M. Chiessi ${ }^{3}$, André O. Sawakuchi ${ }^{4}$, Matthias Zabel ${ }^{2}$, \\ Paul A. Baker ${ }^{5,6}$, Jens Hefter ${ }^{7}$, and Gesine Mollenhauer ${ }^{1,2,7}$ \\ ${ }^{1}$ Department of Geosciences, University of Bremen, 28359 Bremen, Germany \\ ${ }^{2}$ MARUM-Center for Marine Environmental Sciences, University of Bremen, 28359 Bremen, Germany \\ ${ }^{3}$ School of Arts, Sciences and Humanities, University of São Paulo, 03828-000 São Paulo, Brazil \\ ${ }^{4}$ Institute of Geosciences, Department of Sedimentary and Environmental Geology, University of São Paulo, \\ 05508-080 São Paulo, Brazil \\ ${ }^{5}$ Nicolas School of the Environment, Duke University, 301 Old Chemistry, Box 90227, Durham, NC 27708, USA \\ ${ }^{6}$ School of Geological Sciences and Engineering, Yachay Tech, Yachay City of Knowledge, 100650 Urcuqui, Ecuador \\ ${ }^{7}$ Alfred Wegener Institute, Helmholtz Centre for Polar and Marine Research, 25570 Bremerhaven, Germany
}

Correspondence to: Shuwen Sun (shuwen@uni-bremen.de)

Received: 8 November 2016 - Discussion started: 23 November 2016

Revised: 6 April 2017 - Accepted: 11 April 2017 - Published: 17 May 2017

\begin{abstract}
The Amazon River transports large amounts of terrestrial organic carbon $\left(\mathrm{OC}_{\text {terr }}\right)$ from the Andean and Amazon neotropical forests to the Atlantic Ocean. In order to compare the biogeochemical characteristics of $\mathrm{OC}_{\text {terr }}$ in the fluvial sediments from the Amazon drainage basin and in the adjacent marine sediments, we analysed riverbed sediments from the Amazon mainstream and its main tributaries as well as marine surface sediments from the Amazon shelf and fan for total organic carbon (TOC) content, organic carbon isotopic composition $\left(\delta^{13} \mathrm{C}_{\mathrm{TOC}}\right)$, and lignin phenol compositions. TOC and lignin content exhibit positive correlations with $\mathrm{Al} / \mathrm{Si}$ ratios (indicative of the sediment grain size) implying that the grain size of sediment discharged by the Amazon River plays an important role in the preservation of TOC and leads to preferential preservation of lignin phenols in fine particles. Depleted $\delta^{13} \mathrm{C}_{\mathrm{TOC}}$ values $(-26.1$ to $-29.9 \%$ ) in the main tributaries consistently correspond with the dominance of $\mathrm{C} 3$ vegetation. Ratios of syringyl to vanillyl (S / V) and cinnamyl to vanillyl (C / V) lignin phenols suggest that non-woody angiosperm tissues are the dominant source of lignin in the Amazon basin. Although the Amazon basin hosts a rich diversity of vascular plant types, distinct regional lignin compositions are not observed. In the marine sediments, the distribution of $\delta^{13} \mathrm{C}_{\mathrm{TOC}}$ and $\Lambda 8$ (sum of eight lignin phenols in organic carbon (OC), expressed as
\end{abstract}

$\mathrm{mg} / 100 \mathrm{mg}$ OC) values implies that $\mathrm{OC}_{\text {terr }}$ discharged by the Amazon River is transported north-westward by the North Brazil Current and mostly deposited on the inner shelf. The lignin compositions in offshore sediments under the influence of the Amazon plume are consistent with the riverbed samples suggesting that processing of $\mathrm{OC}_{\text {terr }}$ during offshore transport does not change the encoded source information. Therefore, the lignin compositions preserved in these offshore sediments can reliably reflect the vegetation in the Amazon River catchment. In sediments from the Amazon fan, low lignin content, relatively depleted $\delta^{13} \mathrm{C}_{\mathrm{TOC}}$ values and high $(\mathrm{Ad} / \mathrm{Al})_{\mathrm{V}}$ ratios indicating highly degraded lignin imply that a significant fraction of the deposited $\mathrm{OC}_{\text {terr }}$ is derived from petrogenic (sourced from ancient rocks) sources.

\section{Introduction}

Rivers deliver annually about $200 \mathrm{Tg}$ of particulate organic carbon (POC) to the oceans (Galy et al., 2007, 2015; Ludwig et al., 1996; Schlünz and Schneider, 2000), which is predominantly deposited on continental shelves and slopes (Hedges and Keil, 1995). Terrestrial organic carbon $\left(\mathrm{OC}_{\text {terr }}\right)$ buried in marine sediments has been intensely studied in order to reconstruct climate and environmental conditions on 
land (Bendle et al., 2010; Collins et al., 2014; Vogts et al., 2012) with rivers playing a role not only as conduits between terrestrial and marine reservoirs but also as efficient reactors of the $\mathrm{OC}_{\text {terr }}$ (Aufdenkampe et al., 2011; Battin et al., 2009). During transport in fluvial systems, $\mathrm{OC}_{\text {terr }}$ is subject to various natural processes, such as selective preservation within the watershed and microbial degradation, as well as anthropogenic processes associated with land use change (Jung et al., 2014; Wang et al., 2015; Wu et al., 2007). In marine environments, $\mathrm{OC}_{\text {terr }}$ mixes with marine organic carbon and experiences further diagenetic alteration (Aller and Blair, 2006). The refractory fractions of $\mathrm{OC}_{\text {terr }}$, which survive these processes, are preserved at sites of sediment deposition. As a result of this extensive processing, the climatic and environmental information recorded by $\mathrm{OC}_{\text {terr }}$ in marine sediments may be subject to temporal and spatial offsets. Hence, a comparison between the characteristics of $\mathrm{OC}_{\text {terr }}$ in drainage basins and adjacent continental margins is helpful to decipher which depositional sites can provide reliable marine sedimentary archives and to what extent they reflect climatic and environmental changes within the catchment.

The Amazon River is of special interest due to its large drainage basin size and discharge of $\mathrm{OC}_{\text {terr }}$ to the ocean. Previous studies that assessed the fate of $\mathrm{OC}_{\text {terr }}$ transported and discharged by the Amazon mainly relied on bulk organic parameters, isotope compositions of total organic carbon (TOC) $\left(\delta^{13} \mathrm{C}_{\mathrm{TOC}}\right.$ and $\left.\Delta^{14} \mathrm{C}_{\mathrm{TOC}}\right)$ (Bouchez et al., 2014) as well as on analyses of various biomarkers (e.g. lignin, plant waxes and tetraether lipids) (Zell et al., 2014). Based on the correlation between TOC contents and $\mathrm{Al} / \mathrm{Si}$ ratios, the latter being indicative of grain-size variations, Bouchez et al. (2014) showed a distinct mineral and size class association of particulate organic matter (POM), which in turn affects its transport in the fluvial system. Moreover, the $\delta^{13} \mathrm{C}_{\mathrm{TOC}}$ and $\Delta{ }^{14} \mathrm{C}_{\mathrm{TOC}}$ of POM indicated that rock-derived POM accounts for a significant proportion of riverbed sediments. Hedges et al. (1986) reported lignin compositions of typical plant tissues in the Amazon basin and found that POM has distinct lignin compositions in different grain-size fractions.

Offshore the Amazon River mouth, the predominant depocentre of terrestrial organic matter, has been shown to change between glacial and interglacial periods (Schlünz et al., 1999). During glacials (i.e. low sea level), most of the Amazon-derived $\mathrm{OC}_{\text {terr }}$ is deposited on the Amazon fan, while during interglacials (i.e. high sea level), along-shore currents result in deposition of $\mathrm{OC}_{\text {terr }}$ on the continental shelf north-west of the Amazon River mouth. Terrestrial climate and vegetation from the last glacial period has thus been reconstructed by analysing molecular biomarkers, such as lignin, plant-wax lipids, and branched glycerol dialkyl glycerol tetraethers (GDGTs) in sediment cores recovered from the Amazon fan (Bendle et al., 2010; Boot et al., 2006; Goñi et al, 1997; Kastner and Goñi, 2003).
Lignin is a useful tracer for $\mathrm{OC}_{\text {terr }}$ because it is exclusively produced by vascular plants and accounts for about $20-30 \%$ of dry biomass in woody plants (Zhu and Pan, 2010) and $15-20 \%$ in grasses (Perez-Pimienta et al., 2013). It is relatively resistant to microbial degradation (Killops and Killops, 2005) and abundant in many environments (e.g. Kuzyk et al., 2008; Loh et al., 2012; Winterfeld et al., 2015). To date, little is known about the factors influencing lignin composition in the Amazon basin and adjacent marine sediments, its transport pathways in the Amazon continental margin, and the potential of lignin in offshore sedimentary archives to constrain sources and compositions of $\mathrm{OC}_{\text {terr }}$.

Here we determined lignin contents and composition in riverbed sediments of the Amazon River and its lowland tributaries as well as in surface sediments of the Amazon shelf and slope. By doing so, we provide evidence on the spatial distribution of $\mathrm{OC}_{\text {terr }}$, its plant sources, its origin within the catchment, and its dispersal patterns on the Amazon continental margin.

\section{Study area}

The Amazon River originates from the confluence of the Ucayali and Marañon rivers in the Andean region in southwestern Peru and receives numerous tributaries that form the largest hydrographic basin in the world (Goulding et al., 2003). It covers an area of about $6.1 \mathrm{~km} \times 10^{6} \mathrm{~km}$ extending from the Guiana Highlands in the north to the Central Brazil Highlands in the south, and is bordered by the Andes mountain range in the west (Guyot et al., 2007). The Peruvian and Bolivian Andean tributaries Solimões (upper stretch of the Amazon River from its confluence with the Negro River) and Madeira are typical white water rivers. Because they drain the steep slope and rapidly weathering Andean region, they are characterized by high concentrations of suspended sediments and dissolved nutrients (Gibbs, 1967). The other major tributaries in the Amazon basin drain lowland regions and are classified as either black or clear water rivers. The black water rivers, such as the Negro River, are rich in dissolved humic substances derived from podzols and depleted in suspended sediments (Mounier et al., 1999). The clear water rivers (e.g. the Xingu River) have low concentrations of suspended sediments and dissolved organic matter compared to the white and black water rivers, and their clarity allows for high phytoplankton productivity (Junk, 1997; Richey et al., 1990). Although the deforested area of the Amazon basin is increasing significantly in the eastern and south-eastern portions, the remainder of the lowland Amazon basin is largely forested except for some small areas dominated by savannah (Houghton et al., 2001). Elsewhere, some grasses grow along the shoreline regions of white water rivers (Guyot et al., 2007; Hedges et al., 1986).

The Amazon basin annually receives an average of about $2500 \mathrm{~mm}$ rainfall and has the world's largest water discharge 


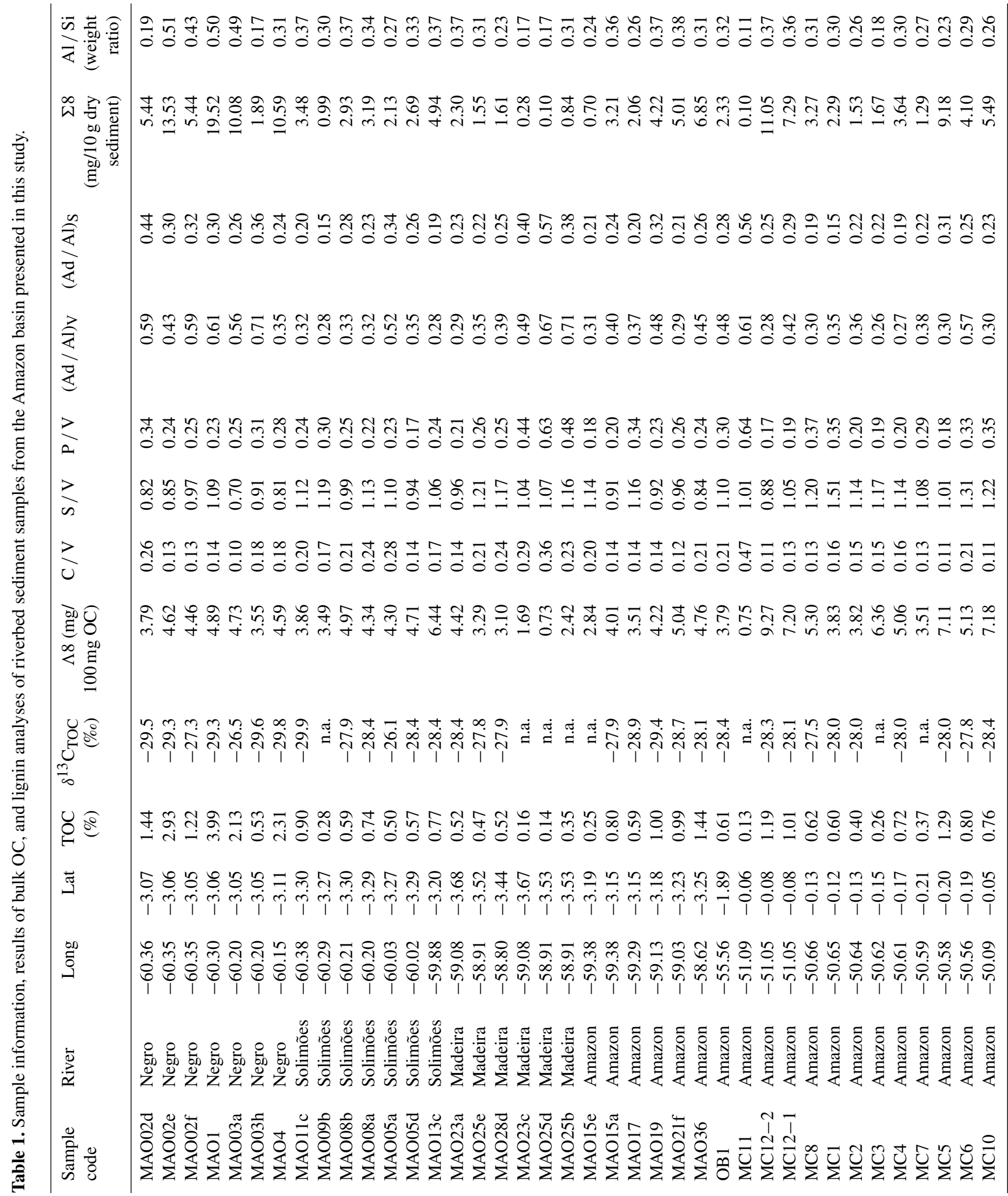




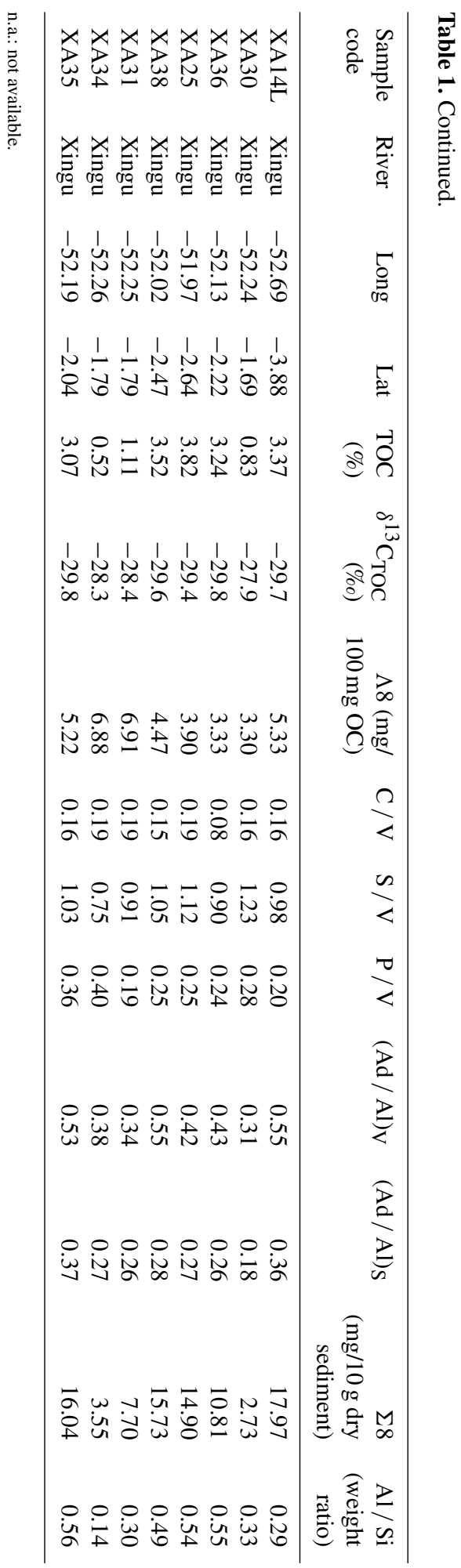

of about $2 \times 10^{5} \mathrm{~m}^{3} \mathrm{~s}^{-1}$ (Callede et al., 2000; Guyot et al., 2007). Up to $40 \mathrm{Tg}$ of carbon are discharged along with 8 $12 \times 10^{11} \mathrm{~kg}$ suspended sediment load each year by the Amazon River into the Atlantic Ocean, which makes the Amazon the largest fluvial source of $\mathrm{OC}_{\text {terr }}$ to the ocean (Dunne et al., 1998; Moreira-Turcq et al., 2003). The Amazonderived plume of water and suspended sediment is advected north-westward along the northern South American coastline by the North Brazil Current, eventually forming the Amazon subaqueous delta-Guianas mud belt extending $1600 \mathrm{~km}$ along the north-eastern coast of South America (Geyer et al., 1996; Nittrouer and DeMaster, 1996). The Amazon fan is located off the northern coast of Brazil centred around $4^{\circ} \mathrm{N}$, extending $700 \mathrm{~km}$ from the shelf break seaward reaching a maximum width of about $650 \mathrm{~km}$. The Amazon fan is largely inactive today, but during past periods of low sea level such as the Last Glacial Maximum, large amount of suspended sediment and bedload were transported via submarine canyons and deposited on the Amazon fan sector (Fan) (Schlünz et al., 1999).

\section{Materials and methods}

\subsection{Sample collection}

Riverbed sediments were collected from the Amazon River mainstream and its main tributaries during two sampling campaigns in November 2011 and May 2012, corresponding respectively to the dry and wet seasons. Sediment samples were retrieved from sites with different channel depths to reflect their range of grain-size variability. A Van Veen grab sampler was used for sampling, and the station locations are shown in Table 1 and Fig. 1a.

Marine surface sediments from the Amazon shelf and fan were collected during two cruises (Table 2, Fig. 1b). The GeoB samples were recovered with a multicorer in February/March 2012 during the R/V Maria S. Merian cruise MSM 20/3, while the other marine surface sediments were taken in February/March 2010 with a box corer deployed from R/V Knorr during cruise KNR197-4. All samples were kept frozen at $-20^{\circ} \mathrm{C}$ before analysis and were subsampled into $1 \mathrm{~cm}$ intervals. The uppermost $2 \mathrm{~cm}$ of GeoB multicore samples and slices of $1 \mathrm{~cm}$ from intervals between 5 and $8 \mathrm{~cm}$ sediment depth of cores taken during cruise KNR197-4 were used in this study.

The $\mathrm{GeoB}$ surface sediments were oven dried at $50^{\circ} \mathrm{C}$, while the riverbed and the other marine surface sediments were freeze dried in a Christ Alpha 1-4 LD plus freeze dryer. After drying, all samples were homogenized for further analysis.

\subsection{Grain-size analysis}

Grain-size analysis was only conducted for marine sediments, because the riverbed sediment samples had already 


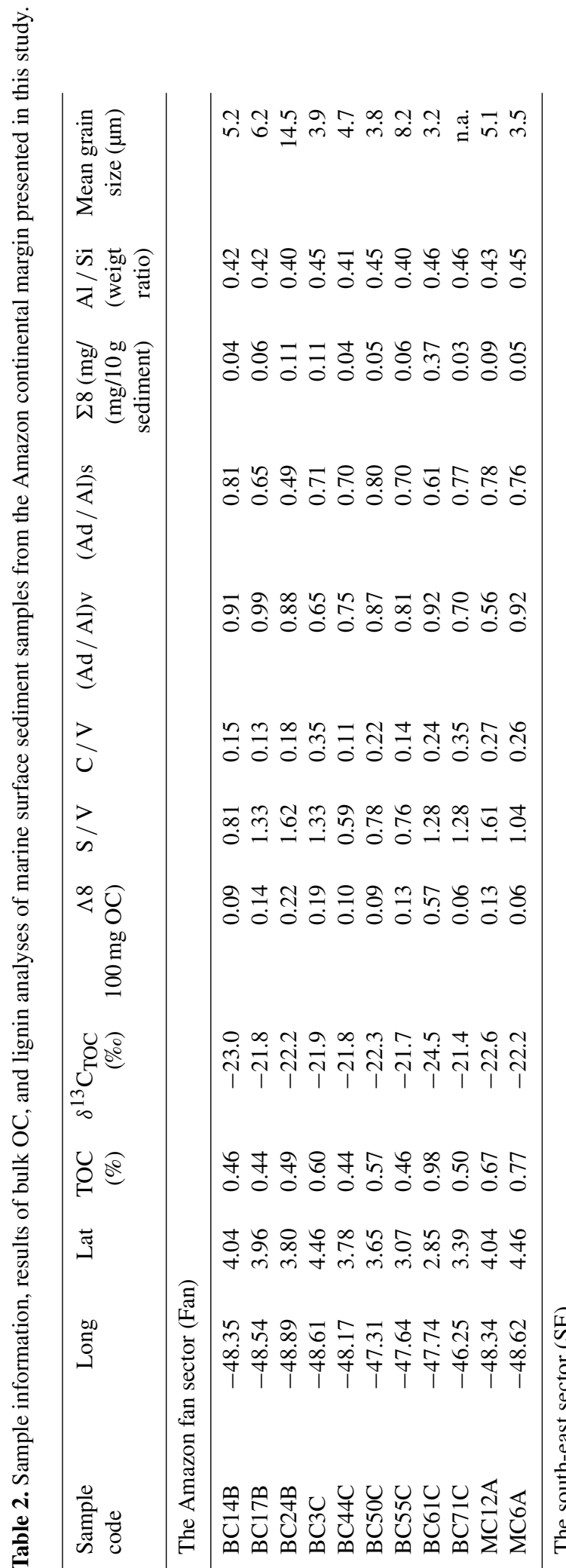

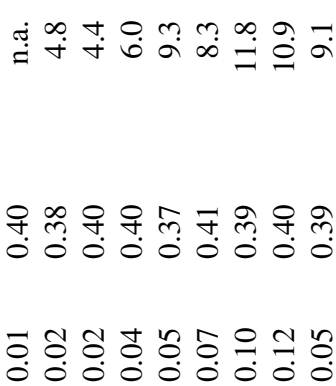

کै?

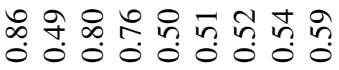

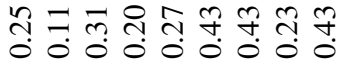

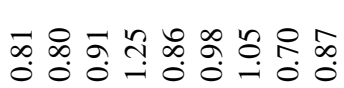

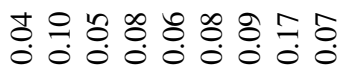

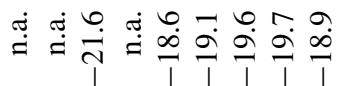

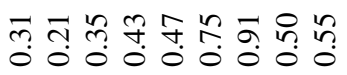

$\infty$ \&

- 00 †

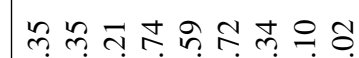

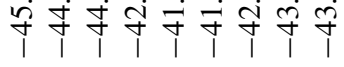

Tंते

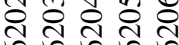

U U U $\cong$

î.

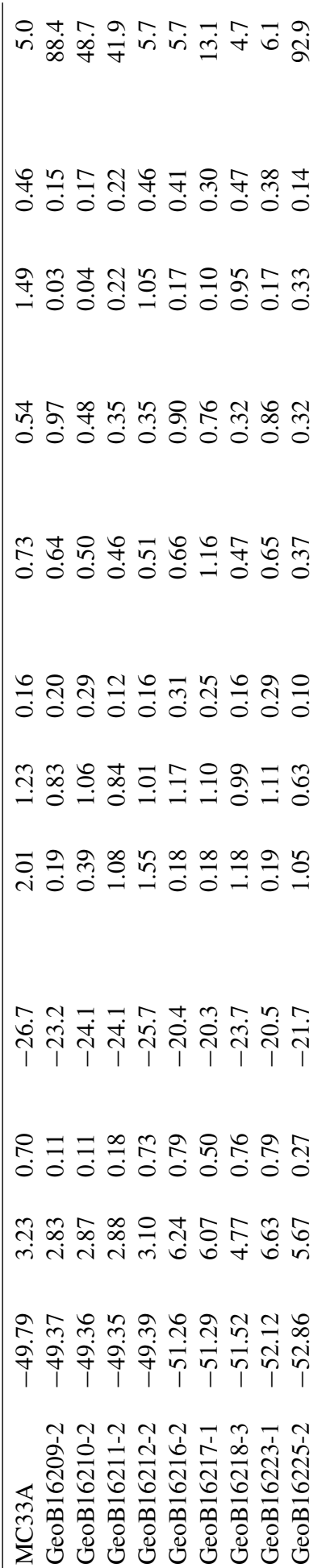




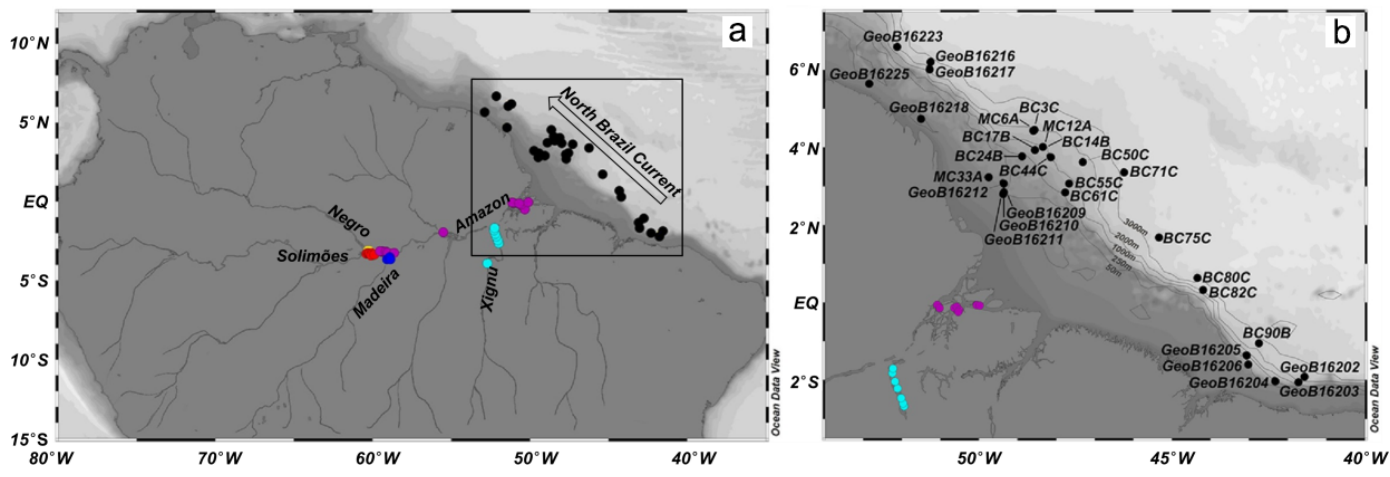

Figure 1. (a) Map of the Amazon basin with the sample locations in individual tributaries and offshore area indicated by coloured dots (red dots is Solimões, yellow dots is Negro, blue dots is Madeira, aqua dots is Xingu, violet dots is Amazon mainstream, black dots is offshore), the black rectangle indicates the area of map (b); (b) map of the Amazon continental margin with the sample locations indicated by black dots. Maps were created using Ocean Data View 4.7.8 (Schlitzer, 2016).

been ground before subsampling. For grain-size measurement of the terrigenous fraction, bulk marine sediments were pre-treated as follows. Samples of about $0.5 \mathrm{~g}$ were successively boiled with $\mathrm{H}_{2} \mathrm{O}_{2}(35 \%), \mathrm{HCl}(10 \%)$, and $\mathrm{NaOH}$ to remove respectively organic matter, carbonate, and biogenic silica. To prevent potential aggregation, $10 \mathrm{~mL}$ of dissolved sodium pyrophosphate $\left(\mathrm{Na}_{4} \mathrm{P}_{2} \mathrm{O}_{7} \times 10 \mathrm{H}_{2} \mathrm{O}\right)$ was added immediately prior to grain-size analysis. Samples were measured using a Laser Diffraction Particle Size Analyser (Beckman Coulter laser particle sizer LS-13320) in 116 size classes ranging from 0.04 to $2000 \mu \mathrm{m}$. All measurements were performed in demineralized and degassed water to avoid interference of gas bubbles.

\subsection{Elemental and bulk isotopic analysis}

About $4 \mathrm{~g}$ of dry sediment was used to measure the $\mathrm{Al}$ and Si elemental concentrations by energy dispersive polarization X-ray fluorescence (EDP-XRF) spectroscopy. The device was operated with the software Spectro X-Lab Pro (version 2.4) using the Turboquant method. Analytical quality of measurements was assessed by repeated analyses of the certified standard reference material MAG-1, and the standard deviation of replicate measurement of sediment samples was better than $0.5 \%$.

After removal of carbonates with $12.5 \% \mathrm{HCl}$ and drying, the TOC content of all samples was determined by a LECO CS 200 CS analysing system. The relative standard deviation of duplicate analyses was better than $1 \%$.

Stable carbon isotopic ratios of TOC $\left(\delta^{13} \mathrm{C}_{\mathrm{TOC}}\right)$ were analysed on a Finnigan MAT Delta plus coupled with a CE elemental analyser and a Con-Flo II interface. Samples were pre-treated by the same method as used for the TOC measurement. $\delta^{13} \mathrm{C}_{\mathrm{TOC}}$ values are reported using the standard notation relative to the Vienna Pee Dee Belemnite standard. The uncertainty was less than $\pm 0.1 \%$, as calculated by long-term repeated analyses of the internal reference sediment (WST2).

\subsection{Lignin phenol analysis}

Alkaline $\mathrm{CuO}$ oxidation was used to obtain eight ligninderived phenols (vanillyl phenols, syringyl phenols, and cinnamyl phenols) and three para-hydroxybenzenes. A CEM MARS5 microwave accelerated reaction system was used to perform alkaline $\mathrm{CuO}$ oxidation of lignin based on the approach described by Goñi and Montgomery (2000). Dried sediment samples (containing about $2-5 \mathrm{mg}$ of TOC) were oxidized with $\mathrm{CuO}(500 \mathrm{mg})$ and ferrous ammonium sulfate $(50 \mathrm{mg})$ in de-aerated $2 \mathrm{~N} \mathrm{NaOH}$ at $150{ }^{\circ} \mathrm{C}$ for $90 \mathrm{~min}$ under a nitrogen atmosphere. After the oxidation, known amounts of recovery standards (ethyl vanillin and transcinnamic acid) were added to each reaction tube. The alkaline supernatant was transferred and acidified to $\mathrm{pH} 1$ by addition of concentrated $\mathrm{HCl}$. Reaction products were extracted twice with ethyl acetate and water in the ethyl acetate solution was removed by addition of $\mathrm{Na}_{2} \mathrm{SO}_{4}$. Ethyl acetate was evaporated under a continuous nitrogen flow. Once dry, $400 \mu \mathrm{l}$ of pyridine was added immediately to redissolve the reaction products. Lignin phenols were analysed by gas chromatography-mass spectrometry (GC-MS). Prior to the injection to the GC-MS, compounds in pyridine were derivatized with bis-trimethylsilyl-trifluoroacetamide (BSTFA) $+1 \%$ trimethylchlorosilane (TMCS) to silylate exchangeable hydrogen. Chromatographic separation was achieved by a $30 \mathrm{~m} \times 0.25 \mathrm{~mm}$ (i.d.) DB-1MS $(0.25 \mu \mathrm{m}$ film thickness) capillary GC column. The temperature programme was $100^{\circ} \mathrm{C}$ initial temperature, $4^{\circ} \mathrm{C} \mathrm{min}^{-1} \mathrm{ramp}$, and $300^{\circ} \mathrm{C}$ final temperature with a hold of $10 \mathrm{~min}$.

The eight lignin-derived phenols obtained by alkaline $\mathrm{CuO}$ oxidation are subdivided into the following groups: the vanillyl (V) phenols include vanillin (Vl), ancetovanillone (Vn), and vanillic acid $(\mathrm{Vd})$; syringyl $(\mathrm{S})$ phenols are syringaldehyde (Sl), acetosyringone ( $\mathrm{Sn})$, and syringic acid $(\mathrm{Sd})$; and cinnamyl (C) phenols consist of $p$-coumaric acid $(p-\mathrm{Cd})$ and ferulic acid (Fd). The para-hydroxybenzenes include 

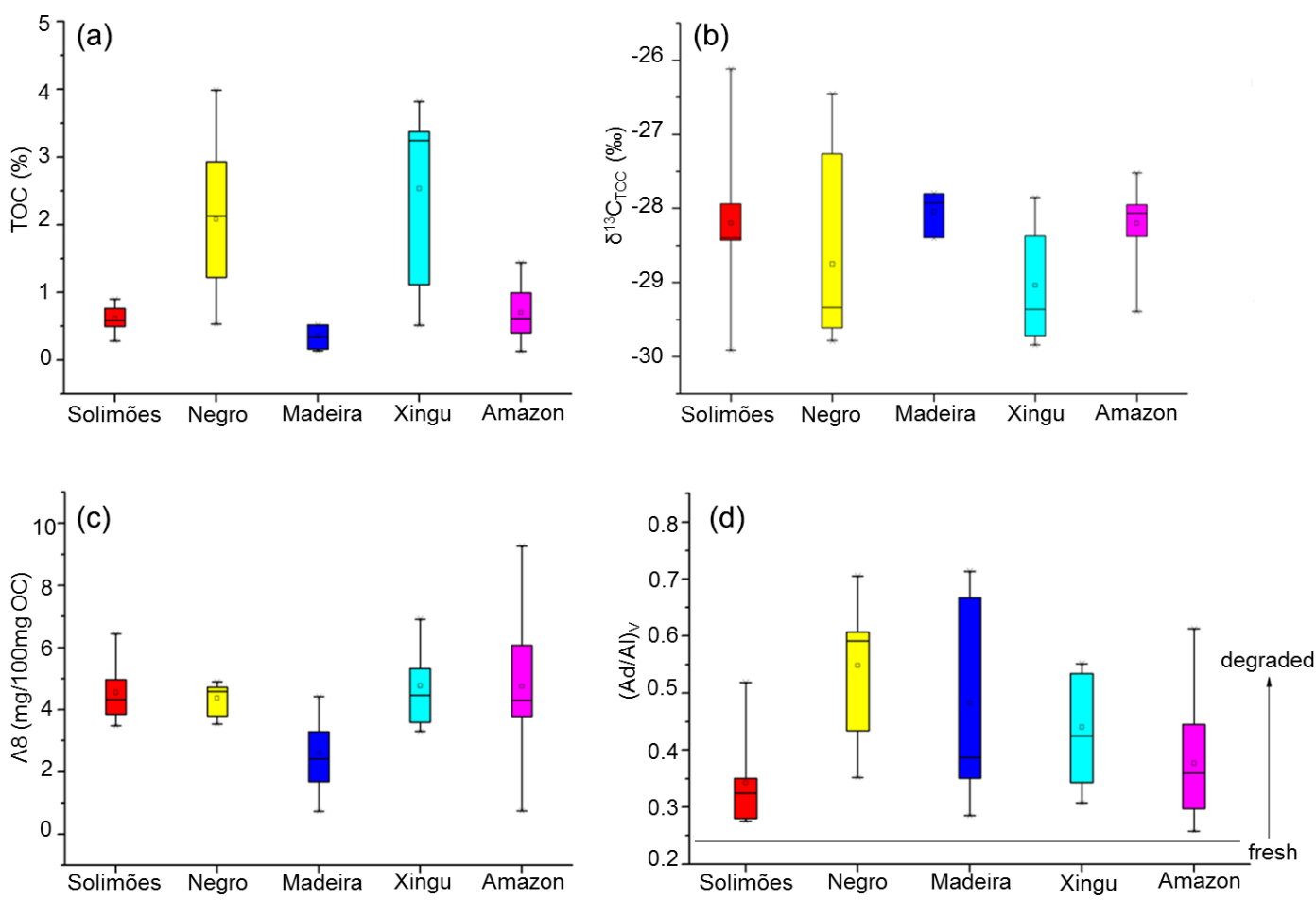

Figure 2. (a) Total organic carbon (TOC) content, (b) stable carbon isotopic composition of total organic carbon $\left(\delta^{13} \mathrm{C}_{\mathrm{TOC}}\right)$, (c) carbonnormalized lignin content $(\Lambda 8)$, and $(\mathbf{d})$ degradation index of lignin $(\mathrm{Ad} / \mathrm{Al})_{\mathrm{V}}$ in different tributaries and in the Amazon mainstream. In $(\mathbf{d})$, $(\mathrm{Ad} / \mathrm{Al})_{\mathrm{V}} \leq 0.24$ suggests fresh vascular plant tissues, whereas $(\mathrm{Ad} / \mathrm{Al})_{\mathrm{V}}>0.24$ reveals degraded plant material. See Table 1 and Fig. 1 for the location of the samples.

$p$-hydroxybenzaldehyde (Pl), $p$-hydroxybenzophenone (Pn), and $p$-hydroxybenzoic acid $(\mathrm{Pd})$. The $\mathrm{C}$ phenols are only present in non-woody tissues of vascular plants while the $\mathrm{S}$ phenols are unique to angiosperms and $\mathrm{V}$ phenols exist in all vascular plants. Therefore, the ratios of $\mathrm{S} / \mathrm{V}$ and $\mathrm{C} / \mathrm{V}$ divide the plant sources of lignin into four types, nonwoody and woody tissues of gymnosperms and angiosperms (Hedges and Mann., 1979a). (Ad/ $\mathrm{Al})_{\mathrm{V}}$ and $(\mathrm{Ad} / \mathrm{Al})_{\mathrm{S}}$ refer to the acid-to-aldehyde ratios of $\mathrm{V}$ and $\mathrm{S}$ phenols, which indicate the degradation of lignin (Ertel and Hedges, 1985).

The lignin phenols and identified compounds were quantified by individual response factors calculated from mixtures of commercially available standards analysed periodically. The yields of $\mathrm{Pl}, \mathrm{Vl}$, and $\mathrm{Sl}$ were calculated by the recovery rate of ethyl vanillin and the recovery rate of transcinnamic acid was applied for the yield estimation of other lignin-derived compounds Kuzyk et al., 2008).

Carbon- and sediment-normalized lignin yields are respectively reported as $\Lambda 8(\mathrm{mg} / 100 \mathrm{mg}$ OC) and $\Sigma 8(\mathrm{mg} / 10 \mathrm{~g}$ dry sediment). These measures indicate respectively the relative contributions of vascular plant material to the TOC, and to the total samples, and were calculated as the sum of S, V, and $\mathrm{C}$ phenols in $100 \mathrm{mg}$ organic carbon and $10 \mathrm{~g}$ dried sample (Hedges and Mann, 1979b).

\section{Results}

\subsection{Riverbed sediments}

\subsubsection{TOC and stable carbon isotopic composition}

Part of the TOC-stable carbon isotopic composition and $\mathrm{Al} /$ Si data were previously published in Häggi et al. (2016). Riverbed sediments contain between 0.13 and $3.99 \%$ dry weight (wt) TOC (Table 1, Fig. 2a). Negro River and Xingu River sediments have similar TOC contents $(0.53-3.99 \%$, mean $=2.08 \pm 1.15 \%, n=7$ and 0.52 $3.82 \%$, mean $=2.44 \pm 1.37 \%, n=8$, respectively), which are higher than the TOC contents in other main tributaries. Consistently low TOC contents are observed in the Madeira River varying from 0.14 to $0.52 \%$ (mean $=0.36 \pm 0.17 \%$, $n=6$ ). Solimões River sediments display TOC contents ranging from 0.28 to $0.90 \%$ with an average of $0.62 \pm 0.20 \%(n=7)$. Amazon River mainstream sediments have intermediate TOC contents ranging from 0.13 to $1.44 \%$ $($ mean $=0.73 \pm 0.36 \%, n=19)$. 
The range of $\delta^{13} \mathrm{C}_{\mathrm{TOC}}$ values of all riverbed samples is from -26.1 to $-29.9 \%$ (Table 1, Fig. 2b). The most enriched $(-26.1 \% \circ)$ and depleted $\left(-29.9 \%\right.$ ) $\delta^{13} \mathrm{C}_{\mathrm{TOC}}$ values are both observed in Solimões River sediments, which have an average value of $-28.2 \pm 1.2 \%$ o $(n=6)$. A similar scatter of $\delta^{13} \mathrm{C}_{\mathrm{TOC}}$ values is obtained from sediments of the Negro River varying between -26.5 and $-29.8 \%$ o (mean $=-28.7 \pm 1.3 \%, n=7$ ). In comparison, narrower ranges are found in the other tributaries and the Amazon River mainstream, with values ranging from -27.8 to $-28.4 \%$ (mean $=-28.0 \pm 0.3 \%, n=3$ ) for the Madeira River, from -27.9 to $-29.8 \%$ ( $n=8$ ) for the Xingu River, and from -27.5 to $-29.4 \%$ (mean $=-28.2 \pm 0.5 \%, n=15)$ for the Amazon River mainstream.

\subsubsection{Lignin phenols}

The $\Lambda 8$ values in riverbed sediments vary from $0.73 \mathrm{mg} / 100 \mathrm{mg}$ OC in the Madeira River to $9.27 \mathrm{mg} / 100 \mathrm{mg}$ OC in the northern channel of the Amazon River mouth (Table 1, Fig. 2c). The highest average $\Lambda 8$ of $4.92 \pm 1.44 \mathrm{mg} / 100 \mathrm{mg}$ OC $(n=8)$ is observed in the Xingu River with values ranging between 3.30 and $6.91 \mathrm{mg} / 100 \mathrm{mg}$ OC. In contrast, Madeira River sediments display the lowest average $\Lambda 8$ value of $2.61 \pm 1.30 \mathrm{mg} / 100 \mathrm{mg}$ OC ( $n=6 ; 0.73$ to $4.42 \mathrm{mg} / 100 \mathrm{mg}$ OC). The $\Lambda 8$ values of samples in the Negro River and the Solimões River vary respectively between 3.55 and $4.89 \mathrm{mg} / 100 \mathrm{mg}$ OC $($ mean $=4.38 \pm 0.51 \mathrm{mg} / 100 \mathrm{mg} \mathrm{OC}, n=7)$ and 3.49 and $6.44 \mathrm{mg} / 100 \mathrm{mg}$ OC $($ mean $=4.59 \pm 0.96 \mathrm{mg} / 100 \mathrm{mg}$ OC, $n=7)$. The $\Lambda 8$ values of the mainstream sediments have the largest variability, from 0.75 to $9.27 \mathrm{mg} / 100 \mathrm{mg}$ OC (mean $=4.88 \pm 1.93 \mathrm{mg} / 100 \mathrm{mg} \mathrm{OC}, n=19)$.

Negro River and Xingu River sediments have higher $\Sigma 8$ values and greater variability, ranging respectively from 1.89 to $19.52 \mathrm{mg} / 10 \mathrm{~g}$ of dry sediment (mean $=9.50 \pm 5.90 \mathrm{mg} / 10 \mathrm{~g}$ dry sediment, $n=7$ ) and from 2.73 to $17.97 \mathrm{mg} / 10 \mathrm{~g}$ of dry sediment $($ mean $=11.18 \pm 5.93 \mathrm{mg} / 10 \mathrm{~g}$ dry sediment, $n=8)$. In contrast, the samples from the other tributaries and the Amazon mainstream display lower $\Sigma 8$ values, $0.99-4.94 \mathrm{mg} / 10 \mathrm{~g}$ of dry sediment $($ mean $=2.91 \pm 1.22 \mathrm{mg} / 10 \mathrm{~g}$ of dry sediment, $n=7$ ) for the Solimões River, $0.10-2.30 \mathrm{mg} / 10 \mathrm{~g}$ of dry sediment (mean $=1.11 \pm 0.85 \mathrm{mg} / 10 \mathrm{~g}$ of dry sediment, $n=6$ ) for the Madeira River and $0.10-11.05 \mathrm{mg} / 10 \mathrm{~g}$ of dry sediment (mean $=3.96 \pm 2.93 \mathrm{mg} / 10 \mathrm{~g}$ of dry sediment, $n=19)$ for the Amazon River mainstream. Apart from the Xingu River, the $\Sigma 8$ values and $\Lambda 8$ values in individual tributaries are well correlated $\left(r^{2}\right.$ from 0.64 to 0.96 , $p<0.05$ ).

$\mathrm{S} / \mathrm{V}$ and $\mathrm{C} / \mathrm{V}$ of all riverbed samples range respectively from 0.70 to 1.51 and 0.08 to 0.47 (Table 1, Fig. 3). Negro River and Xingu River sediments show slightly lower average $S / V$ ratios $(0.88$ and 1.00$)$ than samples from the

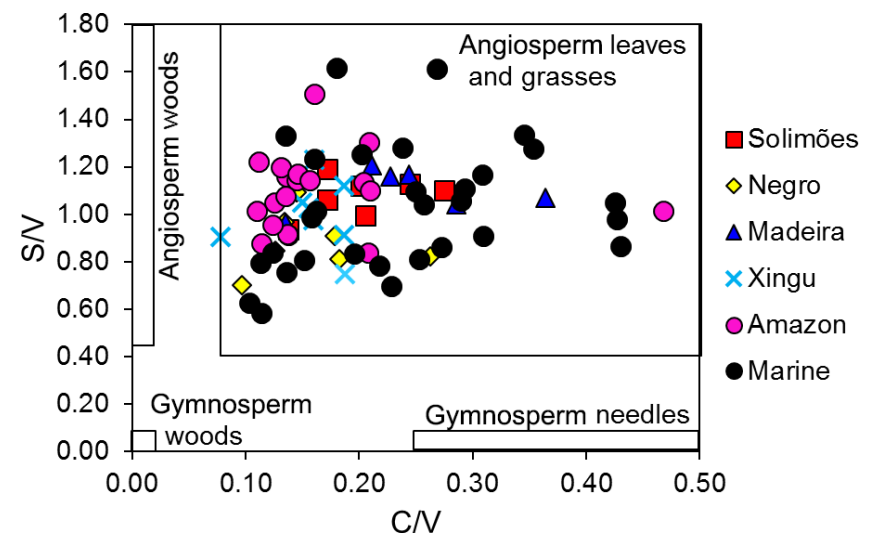

Figure 3. Syringyl / vanillyl (S / V) vs. cinnamyl / vanillyl (C / V) ratios of lignin from Amazon basin riverbed sediments and marine surface sediments from the adjacent continental margin. The black boxes show typical ranges for different vascular plant tissues from the Amazon basin (Hedges et al., 1986; Goñi et al., 1998). See Tables 1 and 2 and Fig. 1 for the location of the samples.

Solimões River, the Madeira River, and the Amazon mainstream $(1.08,1.10$, and 1.09 , respectively). The range of average $\mathrm{C} / \mathrm{V}$ ratios of all tributaries is from 0.16 to 0.24 and the highest mean C / V ratio was observed in the Madeira River. Except for the highest $\mathrm{P} / \mathrm{V}$ ratio in the Madeira River (0.38), the $\mathrm{P} / \mathrm{V}$ ratios in the other tributaries vary only slightly $(0.24-0.27) .(\mathrm{Ad} / \mathrm{Al})_{\mathrm{V}}$ values in all riverbed samples (Table 1 , Fig. 2 d) vary from 0.26 to 0.71 with an average of 0.42 , and $(\mathrm{Ad} / \mathrm{Al})_{\mathrm{S}}$ values range from 0.15 to 0.57 with an average of 0.28 . The $(\mathrm{Ad} / \mathrm{Al})_{\mathrm{V}}$ and $(\mathrm{Ad} / \mathrm{Al})_{\mathrm{S}}$ are correlated $\left(r^{2}=0.76, p<0.05, n=47\right)$, but all $(\mathrm{Ad} / \mathrm{Al})_{\mathrm{S}}$ values are lower than the respective $(\mathrm{Ad} / \mathrm{Al})_{\mathrm{V}}$ values.

\subsubsection{Al / Si}

In riverbed sediments, the $\mathrm{Al} / \mathrm{Si}$ varies from 0.11 to 0.56 (Fig. 4a), which is larger than the $\mathrm{Al} / \mathrm{Si}$ range of riverbed sediments reported by Bouchez et al. (2011). Solimões River sediments have a narrow $\mathrm{Al} / \mathrm{Si}$ range $(0.27-$ $0.37)$ with an average of $0.33 \pm 0.04$. The samples in the Madeira River and the Amazon River mainstream display lower $\mathrm{Al} / \mathrm{Si}$ values $(0.17-0.37$, mean $=0.26 \pm 0.08$, $n=6$ and $0.11-0.38$, mean $=0.29 \pm 0.07, n=19$, respectively). On the contrary, Negro River and Xingu River sediments have larger variations and higher average $\mathrm{Al} / \mathrm{Si}$ ratios $(0.17-0.51$, mean $=0.37 \pm 0.15, n=7$ and $0.14-0.56$, mean $=0.40 \pm 0.15, n=8$, respectively).

\subsection{Marine sediments}

\subsubsection{TOC and stable carbon isotopic composition}

TOC content in the marine surface sediments on the Amazon shelf varies from $0.11 \%$ to $0.98 \%$ (Table 2, Fig. 5a). Three samples near the Amazon River mouth exhibit low TOC 

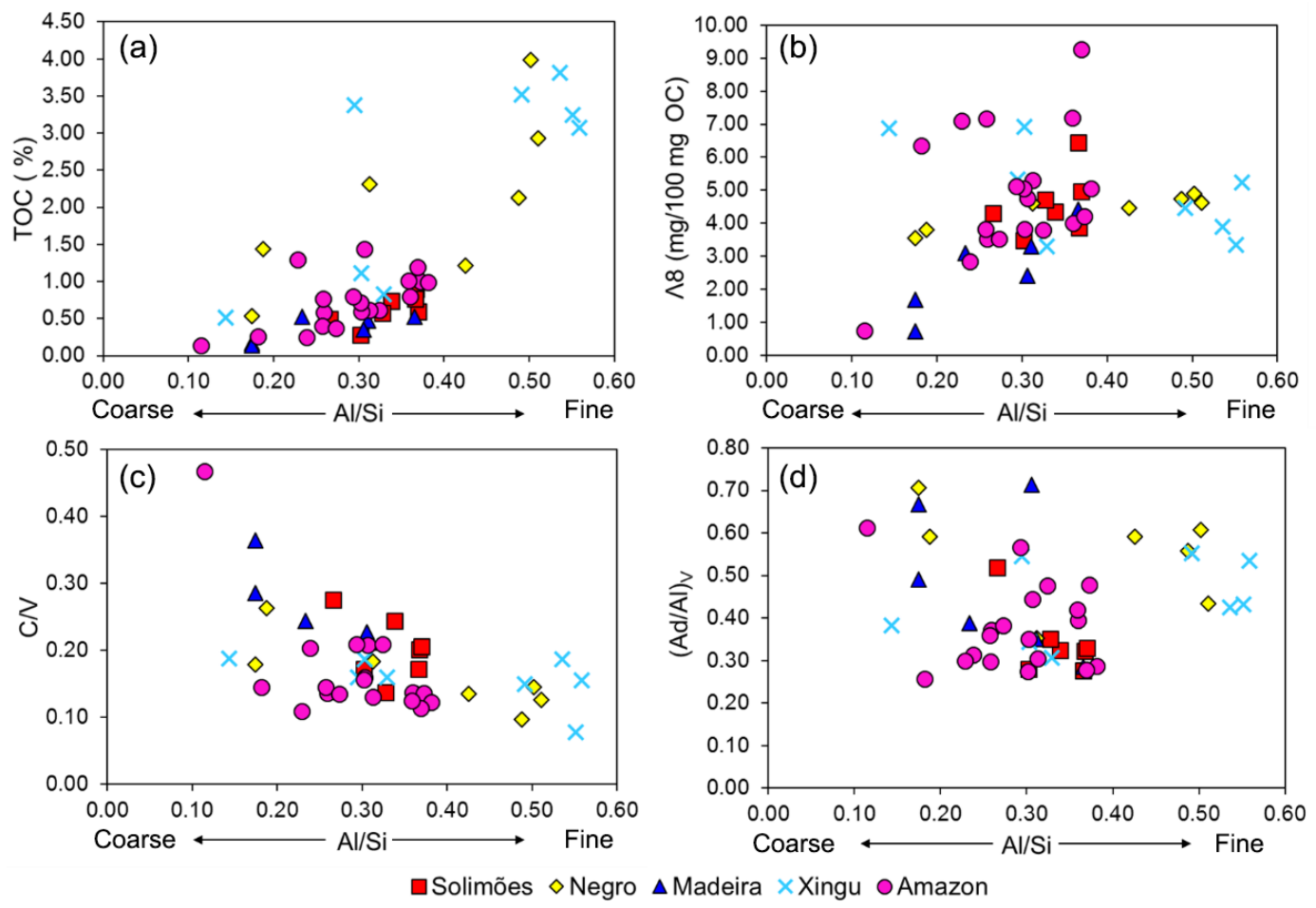

Figure 4. (a) Total organic carbon (TOC) content vs. $\mathrm{Al} / \mathrm{Si}$, (b) carbon-normalized lignin content ( $\Lambda$ 8) vs. Al / Si, (c) cinnamyl / vanillyl $(\mathrm{C} / \mathrm{V})$ ratio vs. $\mathrm{Al} / \mathrm{Si}$, and $(\mathbf{d})$ degradation index of lignin $\left((\mathrm{Ad} / \mathrm{Al})_{\mathrm{V}}\right) \mathrm{vs}$. Al / Si from Amazon basin riverbed sediments. See Table 1 and Fig. 1 for the location of the samples.

contents of less than $0.2 \%(0.13 \pm 0.04 \%$, GeoB16209-2, GeoB16210-2, and GeoB16211-2). The highest TOC content is obtained for BC61C, the southernmost sample from the Amazon fan. The $\delta^{13} \mathrm{C}_{\mathrm{TOC}}$ values for marine surface sediments range from $-18.6 \%$ at station GeoB16202-1, which is located south-east of the river mouth (SE sector), to $-26.7 \%$ at station MC33A (near the river mouth) (Table 1 and Fig. 5b). The samples from the SE sector reveal the most enriched $\delta^{13} \mathrm{C}_{\mathrm{TOC}}$ values between -18.6 and $-21.6 \%$ o $(-19.6 \pm 1.1 \%, n=6)$. The samples collected off the Amazon River mouth exhibit the most depleted $\delta^{13} \mathrm{C}_{\mathrm{TOC}}$ values $(-24.8 \pm 1.4 \%, n=5) . \delta^{13} \mathrm{C}_{\mathrm{TOC}}$ values increase along the shelf towards the north-west from the Amazon River mouth to around $-20.4 \%$ at the north-westernmost stations deeper than $2000 \mathrm{~m}$. Apart from the relatively depleted $\delta^{13} \mathrm{C}_{\mathrm{TOC}}$ value of $-24.5 \%$ at station $\mathrm{BC} 61 \mathrm{C}$, the $\delta^{13} \mathrm{C}_{\mathrm{TOC}}$ values on the Amazon fan range between -21.4 and $-23.0 \%$.

\subsubsection{Lignin phenols}

The $\Lambda 8$ values in marine surface sediments vary from 0.04 to $2.01 \mathrm{mg} / 100 \mathrm{mg}$ OC (Table 2, Fig. 5c). The samples in the SE sector display very low $\Lambda 8$ values $(0.04-0.17 \mathrm{mg} / 100 \mathrm{mg}$ OC), which increase slightly with distance from the Amazon River mouth. Apart from the higher lignin content at station BC61C $(0.57 \mathrm{mg} / 100 \mathrm{mg}$ OC), the samples in the Ama- zon fan (Fan sector) also have low $\Lambda 8$ values ranging from 0.05 to $0.22 \mathrm{mg} / 100 \mathrm{mg}$ OC with a decreasing trend with distance from the Amazon River mouth. The distribution pattern of lignin content in the north-western area (NW sector) is similar to that shown by $\delta^{13} \mathrm{C}$ values. In the NW sector, $\Lambda 8$ values increase first from 0.19 to $2.01 \mathrm{mg} / 100 \mathrm{mg}$ $\mathrm{OC}$ at stations closest to the Amazon River mouth, decrease north-westward, and reach rather constant low values of $0.18 \mathrm{mg} / 100 \mathrm{mg}$ OC on the offshore slope of the NW sector. The $\Sigma 8$ values in marine surface sediments vary from 0.01 to $1.49 \mathrm{mg} / 10 \mathrm{~g}$ of dry sediment and are highly correlated with $\Lambda 8$ values $\left(r^{2}=0.85, p<0.05, n=30\right)$.

Ranges of S / V and C / V ratios in marine sediments are similar to those observed in riverbed sediments. S / V and $\mathrm{C} / \mathrm{V}$ ratios vary respectively from 0.59 to 1.62 and from 0.10 to 0.43 (Table 2, Fig. 3). Sediments in the SE sector have higher $\mathrm{C} / \mathrm{V}$ ratios ( mean $=0.30 \pm 0.11, n=9$ ). The $(\mathrm{Ad} / \mathrm{Al})_{\mathrm{V}}$ and $(\mathrm{Ad} / \mathrm{Al})_{\mathrm{S}}$ values in marine samples vary respectively from 0.37 to 1.16 (Table 2, Fig. 5d) and from 0.32 to 0.97 (Table 2). However, our marine samples show no correlation between $(\mathrm{Ad} / \mathrm{Al})_{\mathrm{V}}$ and $(\mathrm{Ad} / \mathrm{Al})_{\mathrm{S}}$ values. Samples from the Amazon fan exhibit the highest average $(\mathrm{Ad} / \mathrm{Al})_{V, S}$ values of 0.81 and 0.71 . Samples in the SE and NW sectors have similar average $(\mathrm{Ad} / \mathrm{Al})_{\mathrm{V}}$ values $(0.62$ and 0.61 , respectively), but samples from the NW region exhibit larger variation. 

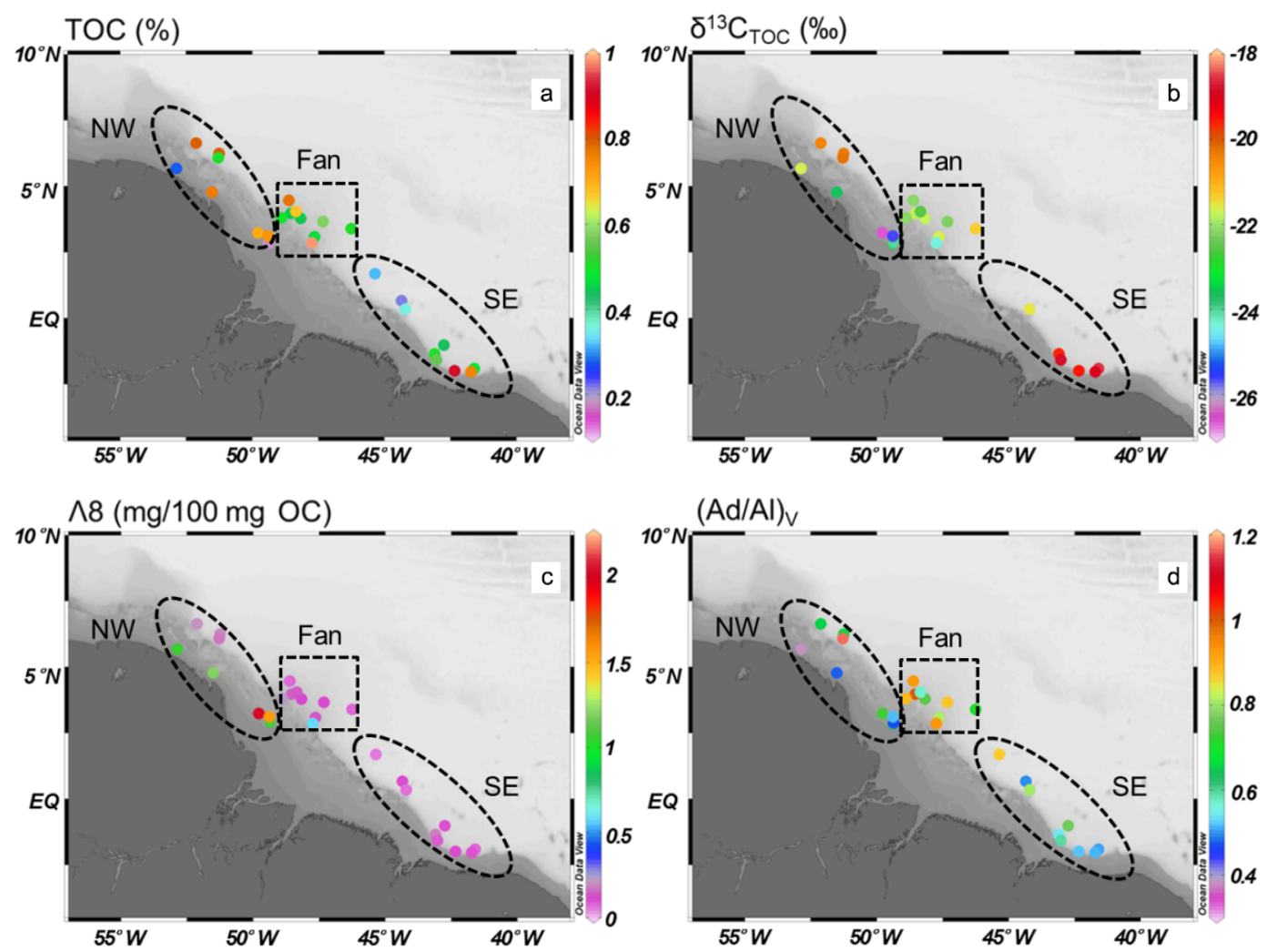

Figure 5. Spatial distribution of (a) total organic carbon (TOC) content, (b) stable carbon isotopic composition of total organic carbon $\left(\delta^{13} \mathrm{C}_{\mathrm{TOC}}\right)$, (c) carbon-normalized lignin content $(\Lambda 8)$, and (d) degradation index of lignin $\left((\mathrm{Ad} / \mathrm{Al})_{\mathrm{V}}\right)$ in marine surface sediment samples from the Amazon continental margin. The dashed ellipses and the rectangle represent the north-west sector (NW), the Amazon fan sector (Fan) and south-east sector (SE).

\subsubsection{Al / Si and grain size}

In marine sediments, the $\mathrm{Al} / \mathrm{Si}$ varies from 0.14 to 0.47 . The $\mathrm{SE}$ and Fan sectors have narrow $\mathrm{Al} / \mathrm{Si}$ ranges, which are respectively $0.37-0.41$ with an average of $0.39 \pm 0.01$ and $0.40-0.46$ with an average of $0.43 \pm 0.02$ (Table 2.). In contrast, the samples in the NW sector display large $\mathrm{Al} / \mathrm{Si}$ variance $(0.14-0.47$, mean $=0.32 \pm 0.14)$.

Grain size of marine sediments is reported as mean grain size and varies between 3.23 and $92.90 \mu \mathrm{m}$ (Table 2). Coincident with the $\mathrm{Al} / \mathrm{Si}$ ratio distribution, samples in the $\mathrm{SE}$ and Fan sectors have narrow grain-size ranges, which are $4.44-11.79 \mu \mathrm{m}$ with an average of $8.07 \pm 2.75 \mu \mathrm{m}$ and 3.23$14.50 \mu \mathrm{m}$ with an average of $5.84 \pm 3.38 \mu \mathrm{m}$, respectively. On the contrary, sediments in the NW sector display wide range grain sizes $(4.74-92.90 \mu \mathrm{m}$, mean $=31.23 \pm 35.19 \mu \mathrm{m})$. The correlation between grain size and $\mathrm{Al} / \mathrm{Si}$ ratio $\left(r^{2}=0.85\right.$, $p<0.05, n=28$ ) indicates that the $\mathrm{Al} / \mathrm{Si}$ ratio is a reliable proxy for the grain size of terrestrial sediments.

\section{Discussion}

\subsection{Lowland Amazon River system}

\subsubsection{Spatial distribution and isotopic composition of $\mathbf{O C}_{\text {terr }}$}

The TOC contents of our riverbed sediments in individual tributaries are larger than values of bedload sediments reported by Bouchez et al. (2014) (mean $=0.23 \pm 0.42 \%$ in the Solimões and Madeira rivers and the Amazon mainstream), but lower than the values of suspended materials (e.g. mean $=1.14 \pm 0.33 \%$ in the Solimões and Madeira rivers and the Amazon mainstream) in the Amazon lowland basin (Hedges et al., 1986; Moreira-Turcq et al., 2003; Bouchez et al., 2014). The distribution of TOC contents basically reflects the characteristics of the tributaries, which are mainly influenced by the content of dissolved organic matter and suspended sediment (Fig. 2a). The relatively high TOC contents in the Negro River are due to the low suspended sediment content and high content of humic substances (Ertel et al., 1986). The Xingu river is characterized by low suspended sediment content and high phytoplankton production, which lead to the high TOC contents in riverbed sediments 
(Moreira-Turcq et al., 2003). In contrast, the Solimões River and the Madeira River, being the primary contributors of the suspended sediment to the Amazon River mainstream, have large suspended sediment load (Moreira-Turcq et al., 2003). Consequently, the low TOC contents in the riverbed sediments in these tributaries are due to dilution by lithogenic material. The lower-intermediate TOC contents for the Amazon River mainstream results from the mixing of different signals from these tributaries with a greater influence from the Solimões and the Madeira rivers.

The $\delta^{13} \mathrm{C}_{\mathrm{TOC}}$ values of our riverbed sediments (i.e. from -26.1 to $-29.9 \%$ ) (Fig. 2b) are similar to the values reported for riverbed sediments (e.g. from -27.6 to $-28.8 \%$ ) and suspended particulate matter (e.g. $-28.3 \pm 1.1 \%$ ) in the Amazon River system in previous studies (Hedges et al., 1986; Cai et al., 1988; Kim et al., 2012; Bouchez et al., 2014). Hedges et al. (1986) studied $\delta^{13} \mathrm{C}_{\mathrm{TOC}}$ values of different organic carbon sources in samples from the Amazon River and found the respective average $\delta^{13} \mathrm{C}_{\mathrm{TOC}}$ values of $\mathrm{C} 3$ tree leaves, woods, macrophyte tissues, and $\mathrm{C} 4$ grasses to be $-30.1 \pm 0.9,-27.6 \pm 1.0,-21.4 \pm 8.4$ and $-12.2 \%$. The total average $\delta^{13} \mathrm{C}_{\text {TOC }}$ value of riverbed sediments in this study $(-28.5 \pm 0.9 \%$ ) confirms the dominant contribution from terrestrial C3 plants. There is no significant difference in the distribution of $\delta^{13} \mathrm{C}_{\mathrm{TOC}}$ values among the sampled tributaries.

\subsubsection{Characteristics of lignin phenols}

With the exception of the samples from the Xingu River $\left(r^{2}=0.02, p=0.71\right)$, all riverbed sediments exhibit a good relation between $\Lambda 8$ values and $\Sigma 8$ values (average $r^{2}=$ $0.76, p<0.05, n=39$ ). In the Xingu River, the high level of in situ primary production and low-turbidity conditions favour the settling of phytoplankton-derived organic matter from the water column (Moreira-Turcq et al., 2003). The deposited phytoplankton-derived organic matter dilutes the abundance of lignin in TOC $(\Lambda 8)$ but has only a small influence on sediment mass and, as a result $\Sigma 8$, resulting in divergence of $\Lambda 8$ and $\Sigma 8$ (Rezende et al., 2010). Based on previous studies, the $\Lambda 8$ values of different organic matter fractions range from 0.45 to $2.40 \mathrm{mg} / 100 \mathrm{mg}$ OC for fine particulate organic matter (FPOM; silt and clay fraction, $<63 \mu \mathrm{m}$ ), and from 1.21 to $10.46 \mathrm{mg} / 100 \mathrm{mg}$ OC for coarse particulate organic matter (CPOM; sand-size fraction, $>63 \mu \mathrm{m}$ ) (Aufdenkampe et al., 2007; Hedges et al., 1986, 2000). In this study, riverbed sediments (Fig. 2c), except for three samples with lignin contents lower than $2.0 \mathrm{mg} / 100 \mathrm{mg}$ OC, had $\Lambda 8$ values (2.42-9.27 mg/100 mg OC) similar to those of CPOM. Most of the $\Lambda 8$ values of our samples are smaller than the average $\Lambda 8$ values of tree wood tissues $(19.3 \mathrm{mg} / 100 \mathrm{mg}$ OC) and C4 grasses $(9.1 \mathrm{mg} / 100 \mathrm{mg}$ OC), and closer to the range of tree leaves and macrophytes (3.7 mg/100 mg OC and $6.4 \mathrm{mg} / 100 \mathrm{mg}$ OC, respectively) (Hedges et al., 1986). This finding is also supported by the distribution of $\mathrm{C} / \mathrm{V}$ and $\mathrm{S} / \mathrm{V}$ ratios. The plot of S / V vs. $\mathrm{C} / \mathrm{V}$ (Fig. 3) indicates that angiosperm leaves are the major origin of lignin in the lower Amazon basin. It is noteworthy that the range of typical $\mathrm{C} / \mathrm{V}$ values for angiosperm leaf material in the Amazon basin is larger (i.e. including $\mathrm{C} / \mathrm{V}$ values as low as 0.07 ) than in other regions (with lowest C / V values around 0.20) (Bianchi et al., 2011; Cathalot et al., 2013; Tesi et al., 2014). The resulting small difference between $\mathrm{C} / \mathrm{V}$ ratios of non-woody and woody tissues of angiosperms in the Amazon region results in a larger uncertainty in inferring the plant sources of lignin. C / V values around 0.1 could be interpreted either as signals exclusively from leaves or as signals from a mixture of woody tissues and leaves. To circumvent this uncertainty, the P / V values are also used to identify the lignin sources. $\mathrm{P}$ phenols in our samples are derived from lignin, as supported from the significant correlation of the content of $\mathrm{P}$ phenols and lignin content $\left(r^{2}=0.50, p<0.05, n=47\right)$. All $\mathrm{P} / \mathrm{V}$ values of our samples $(0.17-0.64)$ are higher than the average $\mathrm{P} / \mathrm{V}$ ratio of woods $(0.05)$ and similar to the range observed for leaves (0.16-6.9) (Hedges et al., 1986). Considering all parameters, non-woody angiosperms are the most likely major source of lignin in the lowland Amazon basin. The slightly higher C / V ratios in the Solimões River (0.20) and the Madeira River (0.24) suggest a small contribution of grass-derived material $(\mathrm{C} / \mathrm{V}>1)$ probably from the Andean highlands (Aufdenkampe et al., 2007; Hedges et al., 2000).

The degradation extent of $\mathrm{OC}_{\text {terr }}$ can be assessed by $(\mathrm{Ad} / \mathrm{Al})_{\mathrm{V}}$ and $(\mathrm{Ad} / \mathrm{Al})_{\mathrm{S}}$ ratios as more degraded lignin yields elevated $(\mathrm{Ad} / \mathrm{Al})_{\mathrm{V}}$ and $(\mathrm{Ad} / \mathrm{Al})_{\mathrm{S}}$ values (Hedges et al., 1988; Opsahl and Benner, 1995). In the case of the Amazon basin, the $(\mathrm{Ad} / \mathrm{Al})_{\mathrm{V}}$ and $(\mathrm{Ad} / \mathrm{Al})_{\mathrm{S}}$ ratios of typical fresh woods and tree leaves both range from 0.11 to 0.24 (Hedges et al., 1986). All of our samples exhibiting values between 0.26 and 0.71 for $(\mathrm{Ad} / \mathrm{Al})_{\mathrm{V}}(\mathrm{Fig}$. 2d) and between 0.15 and 0.57 for $(\mathrm{Ad} / \mathrm{Al})_{S}$ are outside of the range of fresh plant materials, suggesting degraded $\mathrm{OC}_{\text {terr }}$ in all samples. Instead, the $(\mathrm{Ad} / \mathrm{Al})_{\mathrm{V}, \mathrm{S}}$ ratios observed in our samples are within the ranges of suspended particulate solids obtained in the lower Amazon basin and Bolivian headwaters $\left((\mathrm{Ad} / \mathrm{Al})_{\mathrm{V}, \mathrm{S}}\right.$ of $0.21-0.39$ and $0.13-0.22$ for CPOM and $(\mathrm{Ad} / \mathrm{Al})_{\mathrm{V}, \mathrm{S}}$ of $0.38-0.79$ and $0.22-0.41$ for FPOM; Hedges et al., 1986, 2000). The Negro River displayed the highest average $(\mathrm{Ad} / \mathrm{Al})_{\mathrm{V}}$ ratio $(0.55)$, reflecting a greater degree of degradation. This might be indicative of more efficient degradation in the podzols of the lateritic landscapes in the Negro River watershed (Bardy et al., 2011). The (Ad / Al)V ratios in the Solimões and the Madeira rivers increase with increasing $\mathrm{C} / \mathrm{V}$ values $\left(r^{2}=0.50, p<0.05, n=13\right)$, which implies that the plant tissues with higher $\mathrm{C} / \mathrm{V}$ values (higher grass contributions) are more degraded. This further supports the inference that the Solimões and the Madeira rivers receive POC from grass sources from high-altitude watersheds, where deeper soil erosion of more degraded $\mathrm{OC}_{\text {terr }}$ could occur. The degradation status of lignin in riverbed sediments 
does not display a downstream increasing trend and is similar to previous studies on suspended POC of different size fractions. This leads to the conclusion that $\mathrm{OC}_{\text {terr }}$ processing during transport through the Amazon River system probably has limited influence on the composition of lignin recorded in the riverbed sediments and the degradation information likely reflects source characteristics of $\mathrm{OC}_{\text {terr }}$ prior to fluvial transport (Hedges et al., 1986, 1994). This finding contradicts the conclusion of Ward et al. (2013) that lignin is rapidly degraded within the Amazon River. Ward et al. (2013) studied particulate and dissolved lignin in the water column, which is exposed to degradative environments. In contrast, our study focuses on the lignin associated with mineral particles, which are deposited and protected from degradation. This discrepancy highlights the important role of matrix association effects in the preservation of organic matter.

\subsubsection{Sedimentological control on $\mathrm{OC}_{\text {terr }}$ characteristics}

As grain-size data could not be obtained directly on the riverbed sediment samples, we inferred grain-size information based on the relationship between the $\mathrm{Al} / \mathrm{Si}$ ratio and grain size of riverbed sediments observed by Bouchez et al. (2011) in samples from the Amazon basin. High Al / Si indicates aluminium-rich fine-grained sediment, whereas low $\mathrm{Al} / \mathrm{Si}$ suggests silicon-rich particles of larger grain size (Bouchez et al., 2011; Galy et al., 2008).

As expected, the TOC contents increase with $\mathrm{Al} / \mathrm{Si}$ (Fig. 4a), indicating that fine particles, associated with larger specific surface areas and likely rich in clay, carry more TOC than coarser particles. The Negro and the Xingu rivers have larger $\mathrm{Al} / \mathrm{Si}$ and TOC variations, and for a given $\mathrm{Al} / \mathrm{Si}$ ratio, the Negro and the Xingu rivers show higher TOC contents compared to the other tributaries. As these rivers have distinct chemical characteristics and clay mineral composition (e.g. lower $\mathrm{pH}$ in the waters of the Negro River and higher kaolinite content in the sediments of the Negro and the Xingu rivers than in other tributaries; Guyot et al., 2007), the adsorption affinities of $\mathrm{OC}_{\text {terr }}$ on different clay minerals or under different chemical conditions may be distinct.

Different grain-size classes may have not only different TOC content but also the composition of their $\mathrm{OC}_{\text {terr }}$ might vary. For example, previous studies on POM in the Amazon basin found that CPOM has a higher content of lignin phenols than FPOM and that CPOM is composed of fresher lignin with lower C / V ratios (Hedges et al., 1986). Nevertheless, contradictory results were observed in our riverbed sediments. The $\Lambda 8$ values in the Madeira River, the Solimões River, and the mainstream Amazon River show a remarkable increase with decreasing grain size (indicated by increasing $\mathrm{Al} / \mathrm{Si}$ ratios) (Fig. 4b). This rise in lignin content in organic matter associated with finer minerals implies preferential preservation of lignin on finer particles compared with other components. A similar trend has been observed in other environments, such as in surficial sediments of the East China Sea (Wu et al., 2013) and the Iberian margin (Schmidt et al., 2010). However, opposite distribution patterns with lignin enriched in coarser size classes and low density fractions have been found in sediments from the Washington margin (Keil et al., 1998) and the Laptev Sea (Tesi et al., 2016). This is likely because co-deposited plant debris preferentially accumulates within coarser and low density fractions. Thus, the apparent discrepancy between these studies may derive from the different methods employed, i.e. partitioning sediments into discrete size and density fractions (Keil et al., 1998; Tesi et al., 2016) vs. characterizing the mean grain size of bulk sediments (Wu et al., 2013; Schmidt et al., 2010, and our study). On the other hand, the distinct environmental settings in which these studies were conducted, may influence the grain-size distribution of lignin. The Amazon River drains tropical lowlands where degradation on land is efficient, and the turbid waters of the Amazon River might limit the settling of plant fragments. Consequently, in our riverbed samples sedimentary organic matter likely contains only a small contribution of plant debris, whereas less efficient degradation on land in the colder climates of the higher latitudes will result in deposition of more coarse plant debris. In the Negro River, there is only a slight increase in $\Lambda 8$ values as mineral particles become finer, probably as a result of the large amount of sediment-associated chemically stable humic substances (Hedges et al., 1986), in which the lignin content is relatively constant. However, Xingu River sediments exhibit decreasing $\Lambda 8$ values with decreasing grain size probably because the lignin content in finer particles from the Xingu River is diluted by other non-lignin organic components. With respect to the indicator of plant sources (Fig. 4c), the C / V ratios for samples from the Madeira River, the Solimões River, and the Negro River decrease with decreasing grain size, which implies that lignin with higher $\mathrm{C} / \mathrm{V}$ ratios is typically enriched in coarser particles. This suggests that the non-woody tissues with higher proportions of cinnamyl phenols are enriched in coarse-grained sediments. Xingu River and Amazon River mainstream sediments present no pronounced trend between $\mathrm{C} / \mathrm{V}$ ratios and $\mathrm{Al} / \mathrm{Si}$ values.

$(\mathrm{Ad} / \mathrm{Al})_{\mathrm{V}}$ values for all riverbed sediments do not show any obvious relationship with $\mathrm{Al} / \mathrm{Si}$ (Fig. 4d). Only Madeira River and Solimões River sediments exhibit decreasing $(\mathrm{Ad} / \mathrm{Al})_{\mathrm{V}}$ values with increasing $\mathrm{Al} / \mathrm{Si}$, which suggests that lignin associated with larger mineral particles is more degraded. This observation implies preferential preservation of lignin in finer-grained sediments due to better protection against oxidative degradation (Killops and Killops, 2005). Like the correlation between $\Lambda 8$ values and $\mathrm{Al} / \mathrm{Si}$, our observation on $(\mathrm{Ad} / \mathrm{Al})_{\mathrm{V}}$ values is different to the trends found by Keil et al. (1998) and Tesi et al. (2016), where lower $(\mathrm{Ad} / \mathrm{Al})_{\mathrm{V}}$ values have been found in coarser fractions. Again, this is likely due to the fact that these studies investigated individual grain size and density fractions, and 
that they were conducted in higher latitudes with less efficient processing of plant remains prior to deposition. As a result, fresh plant tissue would be found in the coarse fractions leading to low $(\mathrm{Ad} / \mathrm{Al})_{\mathrm{V}}$ values (see discussion above). Because our sediments likely contain limited amounts of plant debris, the $(\mathrm{Ad} / \mathrm{Al})_{\mathrm{V}}$ are lower in finer sediments implying that lignin is better preserved in finer-grained particles. In previous studies on suspended sediments, lignin in the coarse fractions is more abundant and less degraded compared to the counterpart in fine fractions (e.g. Hedges et al., 1986). In contrast, our results for riverbed sediments suggest that lignin is preferentially preserved and better protected against degradation on fine-grained material. The different grain-size effects on $\mathrm{OC}_{\text {terr }}$ composition between suspended and riverbed sediments suggest that there are other processes working on $\mathrm{OC}_{\text {terr }}$ in suspended sediments and riverbed sediments, which cause post-depositional changes in the $\mathrm{OC}_{\text {terr }}$ characteristics.

In summary, our data indicate that lignin derives mainly from non-woody tissues of angiosperms in the lowland Amazon basin, and there is little evidence for contribution from C4 plants to riverbed sediments. Grain size plays an important role in $\mathrm{OC}_{\text {terr }}$ preservation and lignin composition in the Amazon River. Fine inorganic particles have high adsorption affinity for $\mathrm{OC}_{\text {terr }}$, especially for lignin compared to other $\mathrm{OC}_{\text {terr }}$ components and efficiently protect lignin from degradation.

\subsection{Amazon shelf and fan}

\subsubsection{Spatial distribution and characteristics of $\mathrm{OC}_{\text {terr }}$ and lignin phenols}

Because of the depleted average $\delta^{13} \mathrm{C}_{\mathrm{TOC}}$ values of the riverbed sediments $(-28.5 \pm 0.9 \%$ ), contribution of $\mathrm{C} 4$ plants is not expected in the offshore sediments affected by the Amazon outflow. Therefore, enriched ${ }^{13} \mathrm{C}_{\mathrm{TOC}}$ values in the SE sector $(-18.6$ to $-21.6 \%$ ) likely indicate organic matter predominantly of marine origin. $\delta^{13} \mathrm{C}_{\mathrm{TOC}}$ values in the Amazon fan sector ranging from -21.4 to $-24.5 \%$ o (Fig. 5b) also reflect dominantly marine organic matter. These values are within the range of published values for high sea level periods (Schlünz et al., 1999), when most terrestrial POM discharged from the Amazon River is transported to the north-western shelf. In the NW sector, increasing $\delta^{13} \mathrm{C}_{\text {TOC }}$ values with distance from the Amazon River mouth indicate that the terrestrial POM input from the Amazon River transported to the NW by the North Brazil Current is increasingly diluted by marine organic matter. $\mathrm{OC}_{\text {terr }}$ is dominant on the continental shelf, corroborating previous results (e.g. Schlünz et al., 1999).

Sediments in the SE sector exhibit much lower $\Lambda 8$ values than observed in the Fan and NW sectors. Here, slightly increasing $\Lambda 8$ values with distance from the Amazon River mouth suggest that this terrestrial material is predominantly

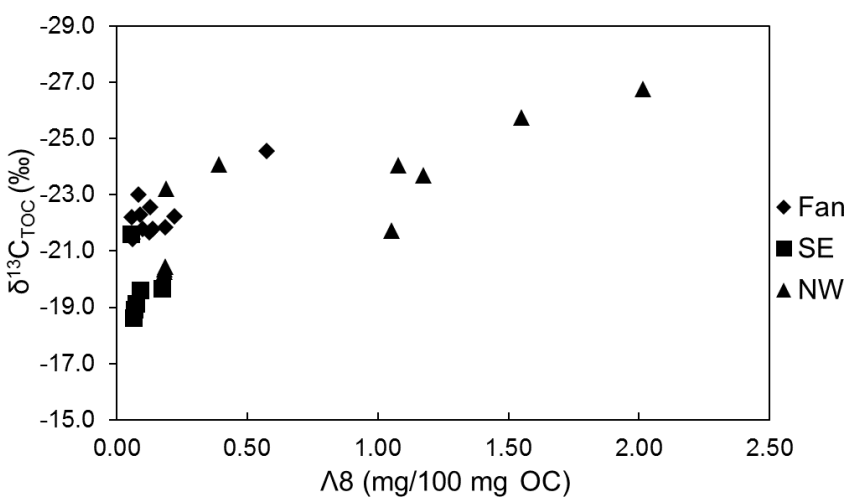

Figure 6. Stable carbon isotopic composition of total organic carbon $\left(\delta^{13} \mathrm{C}_{\mathrm{TOC}}\right)$ vs. carbon-normalized lignin content $(\Lambda 8)$ for marine surface sediment samples from the Amazon continental margin.

supplied by rivers to the south-east of the Amazon mouth and not by the Amazon River itself. The $\Lambda 8$ values in sediments near the Amazon River mouth are highly variable and decrease with distance from the river mouth to the Fan and NW sectors, reaching very low $\Lambda 8$ values in the slope of the NW sector. Lower lignin contents $\left(0.05-0.32 \mathrm{mg} \mathrm{mg}^{-1} \mathrm{OC}\right)$ have been observed in the deep sea fan sediments measured in the study of Feng et al. (2016), which means there is increasing loss of lignin during the transport seawards to the Fan and NW sectors. $\Lambda 8$ and $\delta^{13} \mathrm{C}_{\mathrm{TOC}}$ values show similar spatial distribution and are positively correlated $\left(r^{2}=0.53\right.$, $p<0.05, n=27$ ) (Fig. 6). The agreement in the spatial patterns of lignin content and isotope composition of organic matter suggest that lignin is a reliable tracer of $\mathrm{OC}_{\text {terr }}$ in the Amazon shelf and fan, and that the SE sector receives little $\mathrm{OC}_{\text {terr }}$ contribution from the Amazon River. The intercept of the correlation between $\Lambda 8$ and $\delta^{13} \mathrm{C}_{\mathrm{TOC}}$ of $\mathrm{NW}$ and Fan sediments $\left(r^{2}=0.58, p<0.05, n=21\right)$ is at $-20.8 \%$, which corresponds to conditions with minimal $\mathrm{OC}_{\text {terr }}$ input to the marine sediments. It should be noted that the samples from the Amazon fan have the same low lignin contents as in the SE sector, which indicates low contribution of $\mathrm{OC}_{\text {terr }}$ from terrestrial vascular plants under modern conditions. However, the Fan sediments show more depleted $\delta^{13} \mathrm{C}_{\mathrm{TOC}}$ than sediments from the SE sector, which implies that a small terrestrial fraction is contained in the organic matter of the modern Fan sediments. Potentially, the $\mathrm{OC}_{\text {terr }}$ from vascular plants deposited in the Amazon fan is readily degraded as indicated, e.g. by the high $(\mathrm{Ad} / \mathrm{Al})_{\mathrm{V}, \mathrm{S}}$ ratios, while the relict $\mathrm{OC}_{\text {terr }}$ is predominantly rock derived (with estimated $\delta^{13} \mathrm{C}_{\mathrm{TOC}}$ between -24.3 and $-25.7 \%$ ) (Bouchez et al., 2014) and responsible for the depleted $\delta^{13} \mathrm{C}_{\mathrm{TOC}}$. Petrogenic organic matter is thus likely a significant component in the offshore sediments because of its refractory nature and resulting high preservation potential.

$\mathrm{C} / \mathrm{V}$ and $\mathrm{S} / \mathrm{V}$ ratios (0.08-0.47 and 0.70-1.57, respectively; Fig. 3) in the entire Amazon shelf and fan are compa- 

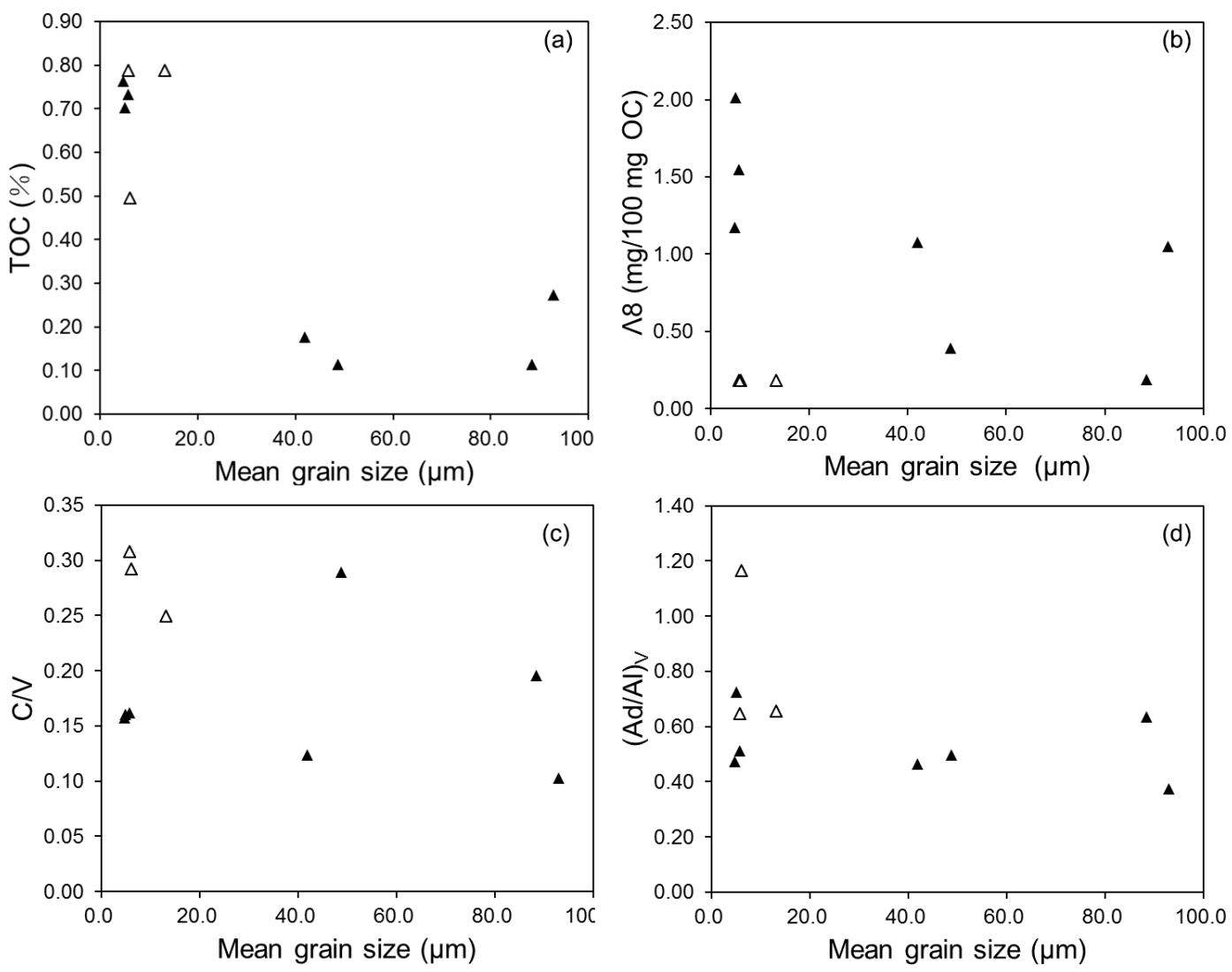

Figure 7. Panels (a), (b), (c), and (d) indicate total organic carbon (TOC) content, carbon-normalized lignin content $(\Lambda 8)$, cinnamyl / vanillyl $(\mathrm{C} / \mathrm{V})$ ratio and lignin degradation index $\left((\mathrm{Ad} / \mathrm{Al})_{\mathrm{V}}\right)$ for marine surface sediment samples from the NW sector vs. mean grain size, respectively. Empty triangles represent the three deepest sites $(>2000 \mathrm{~m})$ far from the coast, and filled triangles represent the other sites in the NW sector with water depth shallower than $100 \mathrm{~m}$. See Table 2 and Fig. 5 for the location of the NW sector.

rable to those in the riverbed sediments of the lowland Amazon basin, which indicates the same predominant source of non-woody angiosperm tissues. This also implies no further alteration of Amazon-derived lignin after it is discharged into the ocean and deposited in marine sediments. Lignin in offshore marine sediments thus can provide reliable evidence for the reconstruction of the vegetation cover in the Amazon basin.

The distribution of the degradation state of lignin based on $(\mathrm{Ad} / \mathrm{Al})_{\mathrm{V}}$ is shown in Fig. 5d. The strikingly elevated $(\mathrm{Ad} / \mathrm{Al})_{\mathrm{V}}$ values in the Amazon fan are probably caused by longer exposure to oxygen (Blair and Aller, 2012) at the sediment-water interface under low sedimentation rates, corroborating our previous interpretation of the low $\Lambda 8$ values but intermediate $\delta^{13} \mathrm{C}_{\mathrm{TOC}}$ values in the Fan sediments (Fig. 6). In the NW sector, there is no obvious decreasing trend of the $(\mathrm{Ad} / \mathrm{Al})_{\mathrm{V}}$ values with the distance from the river mouth. Low $(\mathrm{Ad} / \mathrm{Al})_{\mathrm{V}}$ values found at shallow nearshore sites far from the Amazon River mouth (e.g. GeoB16218-3 and GeoB16225-2) may be due to rapid transport and deposition of the material discharged from the Amazon River (Nittrouer et al., 1995) or contributions from local small rivers, which may carry an indistinguishable lignin signature from the Amazon River. In the study of Feng et al. (2016), the sampling locations in the Amazon deep sea fan are in deeper water depths than our samples $(>4000 \mathrm{~m})$. Nevertheless, very low $(\mathrm{Ad} / \mathrm{Al})_{\mathrm{V}, \mathrm{S}}(0.04-1.3$ and $0.03-0.8$ for $\mathrm{V}$ and $\mathrm{S}$ phenols, respectively) were observed. Neither $\mathrm{S} / \mathrm{V}$ nor $\mathrm{C} / \mathrm{V}$ ratios decrease with $(\mathrm{Ad} / \mathrm{Al})_{\mathrm{V}, \mathrm{S}}$ in the marine sediments, which would be expected because cinammyl and syringyl pheonls are preferentially degraded compared to vanillyl phenols (Benner et al., 1990; Opsahl and Benner, 1995). Despite the fact that the degradation of lignin preserved in marine sediments is slightly higher than that preserved in riverbed sediments, degradation has no major impact on the lignin composition.

\subsubsection{Influence of grain size on $\mathrm{OC}_{\text {terr }}$ deposition in marine sediments}

The grain size and $\mathrm{Al} / \mathrm{Si}$ in the Amazon fan and $\mathrm{SE}$ sectors vary within a rather small range. The grain size and $\mathrm{Al} / \mathrm{Si}$ relationship in the NW sector is in accordance with the results obtained by Bouchez et al. (2011). The sediments in the 
$\mathrm{NW}$ sector have similar $\mathrm{Al} / \mathrm{Si}$ ratios as our riverbed sediments (Table 2), which are correlated with grain size. We use grain-size data for the following discussion of the sedimentological control on the distribution pattern of $\mathrm{OC}_{\text {terr }}$ in the NW sector and refer to the relationship between TOC and $\mathrm{Al} / \mathrm{Si}$ as observed in the riverbed sediments.

Fine sand sediments were observed at the position closest to the Amazon River mouth (GeoB16209-2) and at site GeoB16225-2, which is far from the Amazon River mouth (about $700 \mathrm{~km}$ ) but near the coast in a water depth of $34 \mathrm{~m}$. The sample GeoB16225-2 probably receives additional input from local smaller rivers, from which coarser sediments are discharged. Considering that the characteristics of organic matter in the lowland Amazon basin are almost uniform, the local contributions deposited in GeoB16225-2 cannot reliably be distinguished from the material from the Amazon River system. The trend of increasing TOC contents with decreasing grain size (Fig. 7a) parallels the one demonstrated for the riverbed sediments (Fig. 4a) and in other marine sediments (Keil et al., 1997; Mayer 1994). The lignin content in organic matter $(\Lambda 8)$ and grain size are not significantly related likely because the $\mathrm{OC}_{\text {terr }}$ is mixed with marinederived organic matter in marine environments (Fig. 7b). For example, according to the enriched $\delta^{13} \mathrm{C}_{\mathrm{TOC}}$ values (mean $=-20.4 \pm 0.1 \%$ ), sites GeoB16216-2, GeoB162171 , and GeoB16223-1, which are the sites located farthest offshore, contain the largest fractions of marine organic matter, which reduces their $\Lambda 8$ values to about 0.18 despite their small mean grain size $(<14 \mu \mathrm{m})$. Except for these three locations, the $\Lambda 8$ values are higher in finer-grained sediments than in sandy sediments. This suggests that in marine sediments, as in the riverbed sediments, sorption of lignin on finer sediment is the dominant control on its distribution.

$\mathrm{C} / \mathrm{V}$ and $(\mathrm{Ad} / \mathrm{Al})_{\mathrm{V}}$ values are not related to the grain size in the NW sector (Fig. 7c, d), which suggests that the influence of grain size on lignin composition and degradation is not as important as in the riverbed sediments. The control on the degradation of lignin on the inner Brazil-French Guiana shelf and slope is probably complex and influenced by many factors, including oxygen exposure time, contribution of material by coastal rivers, and sedimentation rate. Compared with riverbed sediments, offshore sediments also exhibit better preservation of organic matter and selective preservation of lignin in finer grain-size particles, but grain size has limited impact on the lignin composition and degradation status.

In summary, the spatial patterns of lignin content and isotope compositions of organic matter corroborates earlier findings (Geyer et al., 1996; Nittrouer and DeMaster, 1996; Schlünz et al., 1999) that material discharged by the Amazon River is transported north-westward by the North Brazil Current. The modern Amazon fan area receives more marine organic matter, and petrogenic organic matter is a significant component of $\mathrm{OC}_{\text {terr }}$ in the Amazon fan sediments. The similarity of lignin composition (C / V and S / V) of marine and riverbed sediments suggests that lignin is a reliable tracer re- flecting the plant source of terrestrial organic matter in the Amazon basin and can be applied to reconstruct vegetation changes and palaeoclimate conditions. Organic matter and lignin content furthermore vary with sediment grain size in the Amazon shelf and slope area and show the same preservation trend, better preservation in finer-grained sediments, as in riverbed sediments. However, lignin composition is rather uniform in sediments of different grain sizes.

\section{Conclusions}

In this study, we use TOC content, stable carbon isotopic composition of organic matter, lignin phenol concentrations, sediment grain size, and $\mathrm{Al} / \mathrm{Si}$ ratios (as indicator of grain size) to investigate the characteristics of $\mathrm{OC}_{\text {terr }}$ in the lowland Amazon basin and its fate on the adjacent continental margin. Depleted $\delta^{13} \mathrm{C}_{\mathrm{TOC}}$ of all riverbed sediments prove that there are limited contributions from $\mathrm{C} 4$ plants to the $\mathrm{OC}_{\text {terr }}$ in the lowland Amazon basin. As evidenced by lignin compositions and stable carbon isotopes of organic matter, the most important plant sources of organic matter in the lowland Amazon basin are non-woody angiosperm C3 plants. There are no distinct regional lignin compositional signatures in the lowland Amazon basin, although the Amazon River receives contributions from tributaries draining different watersheds. Both the bulk organic matter parameters and the lignin compositions were observed to be related to the grain size of the riverbed sediments. Fine inorganic particles in the Amazon River carry more organic matter, preferentially preserving lignin against degradation. Lignin with higher $\mathrm{C} / \mathrm{V}$ ratio is inclined to be adsorbed to coarse inorganic particles.

In marine surface sediments, the bulk parameters and lignin compositions indicate that the continental shelf southeast of the Amazon River mouth receives little $\mathrm{OC}_{\text {terr }}$ from the Amazon River. Most of the $\mathrm{OC}_{\text {terr }}$ discharged from the Amazon River is transported by the North Brazil Current to the north-west and deposited on the continental shelf close to the coast. Modern organic matter in the Amazon fan is composed predominantly of marine-derived organic matter and the terrestrial organic matter undergoes extensive diagenetic alteration before deposition. On the Amazon shelf, the $\mathrm{OC}_{\text {terr }}$ and lignin are both associated preferentially with finegrained sediments. Despite long-distance transport in the marine environment, the lignin composition found in the marine sediments retains its plant source information in accordance with riverbed sediments. Lignin can thus be used to reliably provide assessments on the integrated vegetation cover in the Amazon basin. 
Data availability. The data presented here are available on the Pangaea database (https://doi.pangaea.de/10.1594/PANGAEA. 875162).

Competing interests. The authors declare that they have no conflict of interest.

Acknowledgements. We would like to thank the crews participating in the cruises for providing the samples. We sincerely appreciate the technical support from Jürgen Titschack for grain-size measurement. We thank Maria Winterfeld for laboratory assistance. This study was supported by the Deutsche Forschungsgemeinschaft through the DFG Research Centre/Cluster of Excellence "The Ocean in the Earth System". Shuwen Sun thanks the China Scholarship Council (CSC) and GLOMAR-Bremen International Graduate School for Marine Sciences for additional support. Cristiano M. Chiessi was supported by FAPESP (grant 2012/17517-3) and CAPES (grants 1976/2014 and 564/2015). Sediment sampling in the Amazon River system was funded by FAPESP (grant 2011/06609-1). AOS is supported by CNPq (grant 309223/2014-8). Paul A. Baker is supported by NSF 1338694.

The article processing charges for this open-access publication were covered by the University of Bremen.

Edited by: H. Niemann

Reviewed by: X. Feng and R. Sparkes

\section{References}

Aller, R. C. and Blair, N. E.: Carbon remineralization in the Amazon-Guianas tropical mobile mudbelt: A sedimentary incinerator, Cont. Shelf Res., 26, 2241-2259, doi:10.1016/j.csr.2006.07.016, 2006.

Aufdenkampe, A. K., Mayorga, E., Hedges, J. I., Llerena, C., Quay, P. D., Gudeman, J., Krusche, A. V., and Richey, J. E.: Organic matter in the Peruvian headwaters of the Amazon: Compositional evolution from the Andes to the lowland Amazon mainstem, Org. Geochem., 38, 337-364, doi:10.1016/j.orggeochem.2006.06.003, 2007.

Aufdenkampe, A. K., Mayorga, E., Raymond, P. A., Melack, J. M., Doney, S. C., Alin, S. R., Aalto, R. E., and Yoo, K.: Riverine coupling of biogeochemical cycles between land, oceans, and atmosphere, Front. Ecol. Environ., 9, 53-60, doi:10.1890/100014, 2011.

Bardy, M., Derenne, S., Allard, T., Benedetti, M. F., and Fritsch, E.: Podzolisation and exportation of organic matter in black waters of the Rio Negro (upper Amazon basin, Brazil), Biogeochemistry, 106, 71-88, doi:10.1007/s10533-010-9564-9, 2011.

Battin, T. J., Luyssaert, S., Kaplan, L. A., Aufdenkampe, A. K., Richter, A., and Tranvik, L. J.: The boundless carbon cycle, Nat. Geosci., 2, 598-600, doi:10.1038/ngeo618, 2009.

Bendle, J. A., Weijers, J. W. H., Maslin, M. A., Sinninghe Damsté, J. S., Schouten, S., Hopmans, E. C., Boot, C. S., and Pancost, R. D.: Major changes in glacial and Holocene terrestrial temperatures and sources of organic carbon recorded in the Amazon fan by tetraether lipids, Geochem. Geophy. Geosy., 11, Q12007, doi:10.1029/2010GC003308, 2010.

Benner, R., Hatcher, P. G., and Hedges, J. I.: Early diagenesis of mangrove leaves in a tropical estuary: Bulk chemical characterization using solid-state 13C NMR and elemental analyses, Geochim. Cosmochim. Ac., 54, 2003-2013, doi:10.1016/00167037(90)90268-P, 1990.

Bianchi, T. S., Wysocki, L. A., Schreiner, K. M., Filley, T. R., Corbett, D. R., and Kolker, A. S.: Sources of Terrestrial Organic Carbon in the Mississippi Plume Region: Evidence for the Importance of Coastal Marsh Inputs, Aquat. Geochem., 17, 431-456, doi:10.1007/s10498-010-9110-3, 2011.

Blair, N. E. and Aller, R. C.: The Fate of Terrestrial Organic Carbon in the Marine Environment, Annu. Rev. Mar. Sci., 4, 401-423, doi:10.1146/annurev-marine-120709-142717, 2012.

Boot, C. S., Ettwein, V. J., Maslin, M. A., Weyhenmeyer, C. E., and Pancost, R. D.: A 35,000 year record of terrigenous and marine lipids in Amazon Fan sediments, Org. Geochem., 37, 208-219, doi:10.1016/j.orggeochem.2005.09.002, 2006.

Bouchez, J., Gaillardet, J., France-Lanord, C., Maurice, L., and Dutra-Maia, P.: Grain size control of river suspended sediment geochemistry: Clues from Amazon River depth profiles, Geochem. Geophy. Geosy., 12, Q03008, doi:10.1029/2010GC003380, 2011.

Bouchez, J., Galy, V., Hilton, R. G., Gaillardet, J., MoreiraTurcq, P., Pérez, M. A., France-Lanord, C., and Maurice, L.: Source, transport and fluxes of Amazon River particulate organic carbon: Insights from river sediment depth-profiles, Geochim. Cosmochim. Ac., 133, 280-298, doi:10.1016/j.gca.2014.02.032, 2014.

Cai, D.-L., Tan, F. C., and Edmond, J. M.: Sources and Transport of Particulate Organic Carbon in the Amazon River and Estuary, Estuar. Coast. Shelf S., 26, 1-14, 1988.

Callede, J., Kosuth, P., Loup, J.-L., and Guimarães, V. S.: Discharge determination by Acoustic Doppler Current Profilers (ADCP): a moving bottom error correction method and its application on the River Amazon at Óbidos, Hydrolog. Sci. J., 45, 911-924, doi:10.1080/02626660009492392, 2000.

Cathalot, C., Rabouille, C., Tisnérat-Laborde, N., Toussaint, F., Kerhervé, P., Buscail, R., Loftis, K., Sun, M.-Y., Tronczynski, J., Azoury, S., Lansard, B., Treignier, C., Pastor, L., and Tesi, T.: The fate of river organic carbon in coastal areas: A study in the Rhône River delta using multiple isotopic $\left(\delta^{13} \mathrm{C}, \Delta^{14} \mathrm{C}\right)$ and organic tracers, Geochim. Cosmochim. Ac., 118, 33-55, doi:10.1016/j.gca.2013.05.001, 2013.

Collins, J. A., Schefuß, E., Govin, A., Mulitza, S., and Tiedemann, R.: Insolation and glacial-interglacial control on southwestern African hydroclimate over the past 140000 years, Earth Planet Sc. Lett., 398, 1-10, doi:10.1016/j.eps1.2014.04.034, 2014.

Dunne, T., Mertes, L. A. K., Meade, R. H., Richey, J. E., and Forsberg, B. R.: Exchanges of sediment between the flood plain and channel of the Amazon River in Brazil, Bull. Geol. Soc. Am., 110, 450-467, doi:10.1130/00167606(1998)110<0450:EOSBTF>2.3.CO;2, 1998.

Ertel, J. R. and Hedges, J. I.: Sources of sedimentary humic substances: vascular plant debris, Geochim. Cosmochim. Ac., 49, 2097-2107, doi:10.1016/0016-7037(85)90067-5, 1985. 
Ertel, J. R., Hedges, J. I., Devol, A. H., Richey, J. E., and Ribeiro, M. de N. G.: Dissolved humic substances of the Amazon river system, Limnol. Oceanogr., 31, 739-754, 1986.

Feng, X., Feakins, S. J., Liu, Z., Ponton, C., Wang, R. Z., Karkabi, E., Galy, V., Berelson, W. M., Nottingham, A. T., and West, A. J.: Source to sink: Evolution of lignin composition in the Madre de Dios River system with connection to the Amazon basin and offshore, J. Geophys. Res.-Biogeosci., 121, 13161338, doi:10.1002/2016JG003323, 2016.

Galy, V., France-Lanord, C., Beyssac, O., Faure, P., Kudrass, H., and Palhol, F.: Efficient organic carbon burial in the Bengal fan sustained by the Himalayan erosional system, Nature, 450, 407410, doi:10.1038/nature06273, 2007.

Galy, V., France-Lanord, C., and Lartiges, B.: Loading and fate of particulate organic carbon from the Himalaya to the GangaBrahmaputra delta, Geochim. Cosmochim. Ac., 72, 1767-1787, doi:10.1016/j.gca.2008.01.027, 2008.

Galy, V., Peucker-Ehrenbrink, B., and Eglinton, T.: Global carbon export from the terrestrial biosphere controlled by erosion, Nature, 521, 204-207, doi:10.1038/nature14400, 2015.

Geyer, W. R., Beardsley, R. C., Lentz, S. J., Candela, J., Limeburner, R., Johns, W. E., Castro, B. M., and Soares, I. D.: Physical oceanography of the Amazon shelf, Cont. Shelf Res., 16, 575-616, doi:10.1016/0278-4343(95)00051-8, 1996.

Gibbs, R. J.: Amazon River system: Environmental factors that control its dissolved and suspended load, Science, 156, 1734-1737, 1967.

Goñi, M. A.: Record of terrestrial organic matter composition in Amazon Fan sediments, Proc. ODP, Sci. Results, 155, 519-530, 1997.

Goñi, M. A. and Montgomery, S.: Alkaline CuO Oxidation with a Microwave Digestion System?: Lignin Analyses of Geochemical Samples, Anal. Chem., 72, 3116-3121, doi:10.1021/ac991316w, 2000.

Goulding, M., Barthem, R., and Ferreira, E.: The Smithsonian Atlas of the Amazon, Smithsonian Books, Washington, DC, USA, 2003.

Guyot, J. L., Jouanneau, J. M., Soares, L., Boaventura, G. R., Maillet, N., and Lagane, C.: Clay mineral composition of river sediments in the Amazon Basin, Catena, 71, 340-356, doi:10.1016/j.catena.2007.02.002, 2007.

Häggi, C., Sawakuchi, A. O., Chiessi, C. M., Mulitza, S., Mollenhauer, G., Sawakuchi, H. O., Baker, P. A., Zabel, M., and Schefuß, E.: Origin, transport and deposition of leaf-wax biomarkers in the Amazon Basin and the adjacent Atlantic, Geochim. Cosmochim. Ac., 192, 149-165, doi:10.1016/j.gca.2016.07.002, 2016.

Hedges, J. I. and Keil, R. G.: Sedimentary organic matter preservation: an assessment and speculative synthesis, Mar. Chem., 49, 81-115, 1995.

Hedges, J. I. and Mann, D. C.: The characterization of plant tissues by their lignin oxidation products, Geochim. Cosmochim. Ac., 43, 1803-1807, doi:10.1016/0016-7037(79)90028-0, 1979a.

Hedges, J. I. and Mann, D. C.: The lignin geochemistry of marine sediments from the southern Washington coast, Geochim. Cosmochim. Ac., 43, 1809-1818, doi:10.1016/00167037(79)90029-2, 1979b.

Hedges, J. I., Clark, W. A., Quay, P. D., Richey, J. E., Devol, A. H., and Santos, U. de M.: Compositions and fluxes of particulate organic material in the Amazon River, Limnol. Oceanogr., 31, 717-738, 1986.

Hedges, J. I., Blanchette, R. A., Weliky, K., and Devol, A. H.: Effects of fungal degradation on the $\mathrm{CuO}$ oxidation products of lignin: A controlled laboratory study, Geochim. Cosmochim. Ac., 52, 2717-2726, doi:10.1016/0016-7037(88)90040-3, 1988.

Hedges, J. I., Cowie, G. L., Richey, J. E., Quay, P. D., Benner, R., Strom, M., and Forsberg, B. R.: Origins and processing of organic matter in the Amazon River as indicated by carbohydrates and amino acids, Limnol. Oceanogr., 39, 743-761, doi:10.4319/lo.1994.39.4.0743, 1994.

Hedges, J. I., Mayorga, E., Tsamakis, E., McClain, M. E., Aufdenkampe, A., Quay, P., Richey, J. E., Benner, R., Opsahl, S., Black, B., Pimentel, T., Quintanilla, J., and Maurice, L.: Organic matter in Bolivian tributaries of the Amazon River: A comparison to the lower mainstream, Limnol. Oceanogr., 45, 1449-1466, doi:10.4319/lo.2000.45.7.1449, 2000.

Houghton, R. A., Lawrence, K. T., Hackler, J. L., and Brown, S.: The spatial distribution of forest biomass in the Brazilian Amazon: a comparison of estimates, Glob. Change Biol., 7, 731-746, doi:doi:10.1111/j.1365-2486.2001.00426.x, 2001.

Jung, B.-J., Jeanneau, L., Alewell, C., Kim, B., and Park, J.-H.: Downstream alteration of the composition and biodegradability of particulate organic carbon in a mountainous, mixed land-use watershed, Biogeochemistry, 122, 79-99, doi:10.1007/s10533014-0032-9, 2015.

Junk, W. J.: General aspects of floodplain ecology with special reference to Amazonian floodplains, in: The central Amazon floodplain: Ecology of a pulsing system, Ecological Studies 126, 1, edited by: Junk, W. J., Springer-Verlag, Berlin, Germany, 3-22, 1997.

Kastner, T. P. and Goñi, M. A.: Constancy in the vegetation of the Amazon Basin during the late Pleistocene: evidence from the organic matter composition of Amazon fan deep sea sediments, Geology, 31, 291-294, doi:10.1130/00917613(2003)031<0291:CITVOT>2.0.CO;2, 2003.

Keil, R. G., Mayer, L. M., Quay, P. D., Richey, J. E., and Hedges, J. I.: Loss of organic matter from riverine particles in deltas, Geochim. Cosmochim. Ac., 61, 1507-1511, doi:10.1016/S00167037(97)00044-6, 1997.

Keil, R. G., Tsamakis, E., Giddings, J. C., and Hedges, J. I.: Biochemical distributions (amino acids, neutral sugars, and lignin phenols) among size-classes of modern marine sediments from the Washington coast, Geochim. Cosmochim. Ac., 62, 13471364, doi:10.1016/S0016-7037(98)00080-5, 1998.

Killops, S. and Killops, V.: Introduction to Organic Geochemistry Second Edition, Blackwell Publishing, Malden, USA, 2005.

Kim, J.-H., Zell, C., Moreira-Turcq, P., Pérez, M. A. P., Abril, G., Mortillaro, J.-M., Weijers, J. W. H., Meziane, T., and Sinninghe Damsté, J. S.: Tracing soil organic carbon in the lower Amazon River and its tributaries using GDGT distributions and bulk organic matter properties, Geochim. Cosmochim. Ac., 90, 163180, doi:10.1016/j.gca.2012.05.014, 2012.

Kuzyk, Z. Z. A., Goñi, M. A., Stern, G. A., and Macdonald, R. W.: Sources, pathways and sinks of particulate organic matter in Hudson Bay: Evidence from lignin distributions, Mar. Chem., 112, 215-229, doi:10.1016/j.marchem.2008.08.001, 2008.

Loh, P. S., Chen, C. T. A., Anshari, G. Z., Wang, J. T., Lou, J. Y., and Wang, S. L.: A comprehensive survey of lignin geochem- 
istry in the sedimentary organic matter along the Kapuas River (West Kalimantan, Indonesia), J. Asian Earth Sci., 43, 118-129, doi:10.1016/j.jseaes.2011.09.005, 2012.

Ludwig, W., Probst, J.-L., and Kempe, S.: Predicting the oceanic input of organic carbon by continental erosion, Global Biogeochem. Cy., 10, 23-41, doi:10.1029/95GB02925, 1996.

Mayer, L. M.: Relationships between mineral surfaces and organic carbon concentrations in soils and sediments, Chem. Geol., 114, 347-363, doi:10.1016/0009-2541(94)90063-9, 1994.

Moreira-Turcq, P., Seyler, P., Guyot, J. L., and Etcheber, H.: Exportation of organic carbon from the Amazon River and its main tributaries, Hydrol. Proc., 17, 1329-1344, doi:10.1002/hyp.1287, 2003.

Mounier, S., Braucher, R., and Benaïm, J. Y.: Differentiation of organic matter's properties of the Rio Negro basin by crossflow ultra-filtration and UV-spectrofluorescence, Water Res., 33, 2363-2373, doi:10.1016/S0043-1354(98)00456-4, 1999.

Nittrouer, C. A. and DeMaster, D. J.: The Amazon shelf setting: tropical, energetic, and influenced by a large river, Cont. Shelf Res., 16, 553-573, doi:10.1016/0278-4343(95)00069-0, 1996.

Nittrouer, C. A., Kuehl, S. A., Sternberg, R. W., Figueiredo Jr., A. G., and Faria, L. E. C.: An introduction to the geological significance of sediment transport and accumulation on the Amazon continental shelf, Mar. Geol., 125, 177-192, doi:10.1016/00253227(95)00075-A, 1995.

Opsahl, S. and Benner, R.: Early diagenesis of vascular plant tissues: Lignin and cutin decomposition and biogeochemical implications, Geochim. Cosmochim. Ac., 59, 4889-4904, doi:10.1016/0016-7037(95)00348-7, 1995.

Perez-Pimienta, J. A., Lopez-Ortega, M. G., Varanasi, P., Stavila, V., Cheng, G., Singh, S., and Simmons, B. A.: Comparison of the impact of ionic liquid pretreatment on recalcitrance of agave bagasse and switchgrass, Bioresour. Technol., 127, 18-24, doi:10.1016/j.biortech.2012.09.124, 2013.

Rezende, C. E., Pfeiffer, W. C., Martinelli, L. A., Tsamakis, E., Hedges, J. I., and Keil, R. G.: Lignin phenols used to infer organic matter sources to Sepetiba Bay - RJ, Brasil, Estuar. Coast. Shelf Sci., 87, 479-486, doi:10.1016/j.ecss.2010.02.008, 2010.

Richey, J. E., Hedges, J. I., Devol, A. H., Quay, P. D., Victoria, R., Martinelli, L., and Forsberg, B. R.: Biogeochemistry of carbon in the amazon river, Limnol. Oceanogr., 35, 352-371, 1990.

Schlünz, B. and Schneider, R. R.: Transport of terrestrial organic carbon to the oceans by rivers: re-estimating flux and burial rates, Int. J. Earth Sci., 88, 599-606, doi:10.1007/s005310050290, 2000 .

Schlünz, B., Schneider, R. R., Müller, P. J., Showers, W. J., and Wefer, G.: Terrestrial organic carbon accumulation on the Amazon deep sea fan during the last glacial sea level low stand, Chem. Geol., 159, 263-281, doi:10.1016/S00092541(99)00041-8, 1999.
Schmidt, F., Hinrichs, K., and Elvert, M.: Sources, transport, and partitioning of organic matter at a highly dynamic continental margin, Mar. Chem., 118, 37-55, doi:10.1016/j.marchem.2009.10.003, 2010.

Tesi, T., Semiletov, I., Hugelius, G., Dudarev, O., Kuhry, P., and Gustafsson, Ö.: Composition and fate of terrigenous organic matter along the Arctic land-ocean continuum in East Siberia: Insights from biomarkers and carbon isotopes, Geochim. Cosmochim. Ac., 133, 235-256, doi:10.1016/j.gca.2014.02.045, 2014.

Tesi, T., Semiletov, I., Dudarev, O., Andersson, A., and Gustafsson, Ö.: Matrix association effects on hydrodynamic sorting and degradation of terrestrial organic matter during cross-shelf transport in the Laptev and East Siberian shelf seas, J. Geophys. Res.Biogeosci., 121, 731-752, doi:10.1002/2015JG003067, 2016.

Vogts, A., Schefuß, E., Badewien, T., and Rullkötter, J.: n-Alkane parameters from a deep sea sediment transect off southwest Africa reflect continental vegetation and climate conditions, Org. Geochem., 47, 109-119, doi:10.1016/j.orggeochem.2012.03.011, 2012.

Ward, N. D., Keil, R. G., Medeiros, P. M., Brito, D. C., Cunha, A. C., Dittmar, T., Yager, P. L., Krusche, A. V., and Richey, J. E.: Degradation of terrestrially derived macromolecules in the Amazon River, Nat. Geosci., 6, 530-533, doi:10.1038/ngeo1817, 2013.

Winterfeld, M., Goñi, M. A., Just, J., Hefter, J., and Mollenhauer, G.: Characterization of particulate organic matter in the Lena River delta and adjacent nearshore zone, NE Siberia - Part 2: Lignin-derived phenol compositions, Biogeosciences, 12, 22612283, doi:10.5194/bg-12-2261-2015, 2015.

Wu, Y., Dittmar, T., Ludwichowski, K.-U., Kattner, G., Zhang, J., Zhu, Z. Y., and Koch, B. P.: Tracing suspended organic nitrogen from the Yangtze River catchment into the East China Sea, Mar. Chem., 107, 367-377, doi:10.1016/j.marchem.2007.01.022, 2007.

Wu, Y., Eglinton, T., Yang, L., Deng, B., and Montluçon, D.: Spatial variability in the abundance, composition, and age of organic matter in sur fi cial sediments of the East China Sea, J. Geophys. Res.-Biogeosci., 118, 1495-1507, doi:10.1002/2013JG002286, 2013.

Zell, C., Kim, J.-H., Hollander, D., Lorenzoni, L., Baker, P., Silva, C. G., Nittrouer, C., and Sinninghe Damsté, J. S.: Sources and distributions of branched and isoprenoid tetraether lipids on the Amazon shelf and fan: Implications for the use of GDGT-based proxies in marine sediments, Geochim. Cosmochim. Ac., 139, 293-312, doi:10.1016/j.gca.2014.04.038, 2014.

Zhu, J. Y. and Pan, X. J.: Woody biomass pretreatment for cellulosic ethanol production: Technology and energy consumption evaluation, Bioresour. Technol., 101, 4992-5002, doi:10.1016/j.biortech.2009.11.007, 2010. 